\title{
Rapid Assessment of Wetland Ecosystem Services (RAWES): An example from Colombo, Sri Lanka
}

\author{
McInnes, R.J. ${ }^{1}$, Everard, M. ${ }^{2}$ \\ ${ }^{1}$ RM Wetlands \& Environment Ltd, Littleworth, Oxfordshire, UK rob@rmwe.co.uk \\ ${ }^{2}$ Faculty of Environment and Technology, University of the West of England, Frenchay Campus, Bristol, UK
}

\begin{abstract}
Wetlands make essential positive contributions to multiple dimensions of human wellbeing. However, recognition of these benefits is often lacking in decision-making, compromising the wellbeing of both the ecosystem and is many linked human beneficiaries. Wetland site managers, decision-makers and stakeholders all need to better understand the benefits provided by wetlands. Despite a plethora of available assessment techniques, very few approaches are genuinely rapid, applicable across different wetland types or consider the realities of time and money resource constraints. The Rapid Assessment of Wetland Ecosystem Services (RAWES) approach is presented as a method that meets these needs, illustrated through its practical application in over 60 different wetland sites supporting development of a Wetland Strategy for the Metro Colombo Region, Sri Lanka. The approach is based on the trained, local assessors using a variety of field indicators in order to assess the positive or negative contribution over 30 wetland ecosystem services provide at local, regional or global scales. Outputs are simplified, signalling to decision-makers the diversity of interlinked ecosystem service outcomes consequent from management policies and actions.
\end{abstract}

Key words

Ecosystem services; rapid assessment; systemic solutions; wetlands; Colombo

\section{Introduction}

Wetland ecosystems are essential to human well-being (Millennium Ecosystem Assessment 2005; Russi et al. 2013). A substantial body of evidence demonstrates that wetlands can deliver a great variety of benefits to human society (Ghermandi et al. 2010). These benefits include, but are not limited to, managing flood risk (Mitsch and Day, 2006), decreasing peak air temperatures (Sun et al., 2012), improving water quality (Shutes, 2001; Dhote and Dixit 2009), protecting coastal communities from storms (Gedan et al. 2011), supporting food production (Lannas and Turpie, 2009; Verhoeven and Setter, 2009), providing vital cultural resources (McGregor et al. 2010) and offering locations for a variety of education and recreation opportunities (Cachelin et al. 2009; Finlayson et al. 2013).

Despite the acknowledged importance of wetlands, their values are routinely overlooked (Mclnnes, 2013a) or underestimated (Turner et al. 2008). They are commonly poorly considered in decisionmaking (Faulkner, 2004; Russi et al. 2013), resulting in continued loss and degradation of wetlands and their services (Davidson 2014). One approach to stemming this loss is to adequately identify and value the ecosystem services that wetlands provide (Maltby and Ormerod, 2011; McInnes, 2013b) and to integrate the values of these services into decision-making frameworks (Hein et al. 2006; Daily and Matson 2008).

A burgeoning body of research (Vihervaara et al. 2010; Milcu et al. 2013) and a vast array of evaluation approaches are available to identify, characterize and value ecosystem services (Waage and Stewart, 2008). A review by Bagstad et al. (2013) considered 17 different tools that assess, 
quantify, model, value and/or map ecosystem services. This review was not exhaustive and numerous other approaches are available for use by academics, private and public bodies and wetland managers (such as those by Maltby (2009), OGP/IPIECA (2011), WBCSD (2011), Stratford et al. (2011), Maes et al. (2012), Everard and Waters (2013) and Peh et al. (2013) to name a few). All of these approaches differ in their application and scope, with many tools being limited in their utility as a result of high time, cost or data requirements rendering their wider uptake unlikely (Bagstad et al. 2013). A further criticism levelled at numerous assessment approaches is the failure to consider adequately spatial and temporal scales of benefits and the nature of the actual beneficiaries (Hein et al. 2006). Furthermore, many approaches pursue an economic valuation of ecosystem services in the hope that it can provide conservation practitioners with a "silver bullet" (Vira and Adams, 2009). Often, advocates of these simplified economic approaches fail to acknowledge that derived monetary values are not robust, the assumptions upon which they are based are munificent and that the output numbers will only represent a snapshot that will inevitably vary in space and time (Spangenberg and Settele, 2010). Such limitations are not new and, in a widely-acknowledged seminal study, Costanza et al. (1997) emphasised such approximations and discrepancies in estimating the value of global natural capital.

A common significant oversight is the inability of these multiple approaches to take a systemic view of the plurality of values provided by wetland ecosystems (Everard and McInnes, 2013). They thereby tend to emphasise a limited subset of benefits which in turn reflects a reductive, disciplinebound and legislatively-constrained paradigm (Everard, 2016). As an antidote to many of the published approaches, The Economics of Ecosystems and Biodiversity (TEEB) study advocates a tiered or hierarchical approach which seeks to recognize, demonstrate and capture the value of the services (TEEB 2010). Under some circumstances, the ability to simply recognize value may be sufficient to highlight important ecosystem services; monetary valuation may be unnecessary, or even counterproductive, if it is seen as contrary to cultural norms or fails to reflect a plurality of social values (Defra, 2007, TEEB 2010). Furthermore, the under-recognition of wetland ecosystem services undermines biodiversity conservation arguments, weakens the case for protection or restoration, and ultimately impacts on human well-being (Mclnnes 2013a).The recognition of benefits sensu TEEB (2010) can be achieved through field observation, re-assembling expert and indigenous knowledge, processing published information and/or through dialogue with relevant stakeholders (Wattage and Mardle, 2005; McInnes et al. 2016a). Such a qualitative or relative assessment approach has been explicitly advocated to demonstrate the value of wetland ecosystems (Russi et al. 2013). Whilst there is an inherent uncertainty in taking this heuristic approach, significant merit remains by providing an overview of the multiplicity of values for any wetland area (Mclnnes, 2013a). The outputs from such a process can provide a qualitative or relative assessment of the range of ecosystem services provided by a wetland and a rapid and comprehensive overview of the various benefits provided by wetlands across a large geographic area.

This paper reviews the Rapid Assessment of Wetland Ecosystem Services (RAWES) approach. This is a technique that has been developed through an iterative process of field trials at numerous wetland sites in the United Kingdom, India, Chad and Ireland, in considerations of approaches to urban drainage (Everard et al. 2016) and through dialogue with stakeholders and potential end-users such as site managers, academics, non-governmental organisations and intergovernmental bodies, such as the Ramsar Convention. The approach seeks to address the genuine resource (time and financial) and data constraints faced by many wetland managers and also attempts to resolve issues relating to scale and the scope of beneficiaries. Results from an extensive field trial undertaken across the wetlands of urban Colombo, Sri Lanka, are presented in order to evaluate the utility, reliability and application of the RAWES approach. 


\section{The RAWES approach to assessing ecosystem services}

\subsection{Need and purpose}

The Ramsar Convention provides a framework for international cooperation and national action for the conservation and wise use of wetlands (Gardner and Davidson 2011). A review of how the Convention reports on ecosystem services demonstrated that there are significant differences among the reporting on ecosystem services and that comprehensive assessments of Ramsar Sites and wider wetlands are poor (Mclnnes et al. 2016b). This review echoed findings from elsewhere which demonstrate a bias towards the reporting on provisioning services at the expense of a comprehensive assessment of a full range of ecosystem services (Seppelt et al. 2011; Mclnnes, 2013b; Plieninger et al. 2013). Therefore, despite the large knowledge-base on wetland ecosystem services and the plethora of assessment procedures available, within the global context of delivering on the wise use of wetlands it is clear that uptake and application is limited.

In a review of the priorities for scientific and technical support to the Ramsar Convention, it has been highlighted that the improved understanding and application of knowledge around wetlands ecosystem services, linked to requests for capacity building, represented the only universal priority across the six Ramsar regions (Mclnnes 2014). In order to satisfy reporting obligations under the Ramsar Convention, and to deliver on the aspiration of conservation and wise use of all wetlands, requires the ability of wetland site managers and relevant stakeholders to assess a broad range of ecosystem services using qualitative, quantitative and monetary approaches (Russi et al., 2013; McInnes et al., 2016). Such assessments must remain cognisant of limitations, including resourcing, access, cooperation and capacity, and therefore should be targeted, intuitive and pragmatic in their approach whilst reconciling the challenges of achieving accuracy and specificity (Villa et al., 2014, Mclnnes et al. 2016b).

The development of the RAWES approach has considered the requirements of the Ramsar Convention, and particularly the need for qualitative assessments which are not resource intensive and which can be applied within the context of Ramsar Convention-related reporting (Mclnnes et al. 2016b). However, consideration has also been given to developing an approach which would have wider utility as part of a broader suite of assessment approaches (TEEB, 2010). Consequently the objective of the RAWES approach is to facilitate a comprehensive assessment of the plurality of benefits provided by a wetland which can be considered genuinely rapid involving limited resources.

Based on an understanding of what is required by a specific, but global, wetland audience, the approach has at its core the realisation that in many situations the access to time, money and detailed information will be limited and such barriers need to be overcome if the full range of values is to be recognised. Furthermore, the development of the RAWES approach recognises that less time-intensive methods can be more practically applied on a wide-scale (Villa et al., 2014). Too often complex or opaque assessments of ecosystem services are limited in their scope and fail to identify the multiplicity of benefits provided by wetlands, inherently assigning a default value of zero to these services and thereby excluding them from decision-making fora (Everard \& Mclnnes, 2013).

\subsection{The RAWES approach}

The RAWES approach builds on similar techniques applied elsewhere (for instance Defra (2007) and Everard and Waters (2013)). A checklist of 37 services grouped into functional categories as defined in the Millennium Ecosystem Assessment (2005), namely provisioning, regulating, cultural and supporting services, acts as an initial aide memoire. It is recognised that supporting services have been redefined by TEEB (2010) and Braat and de Groot (2012) as ecosystem functions rather than services, creating potential problems if they are double-counted with more directly exploited services. The category of supporting services is retained in RAWES as they pertain to recognition of 
the functioning and resilience of productive ecosystems rather than valuation and therefore constitute important considerations in terms of the resilience and capacity of ecosystems to provide wider benefits. They can also be important considerations in management decision-making. The list of services in RAWES is subsequently modified and adapted to the local context through dialogue and consultation with local stakeholders who are familiar with the wetland. Delimitation of the exact area to be assessed is defined objectively by the assessor depending on the purpose or scope of the assessment. The RAWES approach is flexible, allowing assessments to be made on different habitat units within a larger wetland complex or on an entire wetland site. The onus is on the assessor to define the 'wetland' and record the rationale behind the boundaries set and limits used. Since wetland ecosystems can be dynamic or can be subject to change or degradation, an important issue to be addressed is the definition of the condition at the time of the assessment. In some cases, the 'natural' condition will vary over time, and it will be necessary to ensure this temporal pattern is considered in the assessment of ecosystem services. For instance, the assessment could return different outcomes if it is conducted during a drought or when the area is subjected to flooding, both of which may represent natural phenomena within the broader tolerances of the system. In other circumstances a wetland may be subject to on-going degradation, for instance through pollution of surface water or infilling. Therefore, it cannot be safely assumed that the current situation reflects a 'natural' condition, and that service delivery is not already influenced by the prevailing conditions. The key issues are to ensure that a comprehensive range of ecosystem services is assessed, that the evidence used to achieve the assessment outcome is transparent and clear and that the prevailing temporal context is recorded.

The assessment of ecosystem services is based on trained individual assessors considering a range of indicator questions and potential outcomes in order to recognise benefits. Indicators, as proxies or surrogates for more detailed knowledge sources, have been used in other ecosystem service assessments such as in Maltby (2009) or in the incorporation of ecosystem services into National Biodiversity Strategies and Actions Plans (NBSAPS) (UNEP-WCMC 2013).Training in rapid assessment methods has been highlighted as being essential if subjectivity is to be reduced and repeatability of results is be enhanced (Herlihy et al., 2009). Typically, a two-day training course is provided for local assessors which involves classroom sessions on the concepts underpinning ecosystem services and the practical sessions in the field in order to review and understand the range of indicator questions and to derive a consensus regarding the significance and scale of benefit of different ecosystem services. The local assessors should have a broad understanding of wetland ecology and particularly how local communities interact with wetlands. It has been acknowledged that the insights provided by local stakeholders and the requirement to incorporate traditional ecological knowledge into the assessments can improve the understanding of ecosystems (Gagnon and Berteaux, 2009) and can be geographically and temporally more extensive than research-based knowledge (Fraser et al., 2006). Consequently, assessors can have either academic or research-based knowledge or can possess a more practical understanding of wetland management. The objective of training and using local assessors is to embed knowledge in local communities and stakeholders and reduce the need for costly external input. The field assessment requires the assessors to use both their own knowledge of the local wetlands as well as engaging with local stakeholders and residents. The engagement can range from holding informal discussions with stakeholders present at the site during the field assessment or more structured forms including formal discussions with local community leaders, non-governmental organisations or government officials.

The assessors consider all the ecosystem services on the list in Table 1 including any local modifications which have been highlighted during the local training session. Each ecosystem service is assessed using the following relative scale (from Defra 2007):

McInnes, R.J., Everard, M. (2017) Rapid Assessment of Wetland Ecosystem Services (RAWES): An example from Colombo, Sri Lanka. Ecosystem Services. DOI: 10.1016/j.ecoser.2017.03.024 


$\begin{array}{ll}\text { Score } & \text { Assessment of ecosystem service } \\ ++ & \text { Potential significant positive contribution } \\ + & \text { Potential positive contribution } \\ 0 & \text { Negligible contribution } \\ - & \text { Potential negative contribution } \\ -- & \text { Potential significant negative contribution } \\ ? & \text { Gaps in evidence }\end{array}$

Table 1. The initial list of wetland ecosystem services considered by the RAWES approach and examples of the indicator questions considered.

\begin{tabular}{|c|c|c|c|}
\hline & Ecosystem service & Example & $\begin{array}{l}\text { Examples of questions assessors can ask about } \\
\text { this service }\end{array}$ \\
\hline \multirow{10}{*}{ 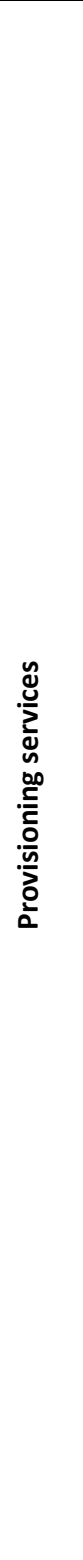 } & Provision of fresh water & $\begin{array}{l}\text { Water used for } \\
\text { domestic drinking } \\
\text { supply, for irrigation, } \\
\text { for livestock, etc. }\end{array}$ & $\begin{array}{l}\text { - Does the wetland provide a source of fresh } \\
\text { water? } \\
\text { - Does the wetland store fresh water for human } \\
\text { use? } \\
\text { - Is the wetland a net source of pollution, } \\
\text { degrading fresh water provision? }\end{array}$ \\
\hline & Provision of food & Crops, fruit, fish, etc. & $\begin{array}{l}\text { - What is grown in the wetland, either formally } \\
\text { or from informal harvesting? } \\
\text { - Are animals are harvested from the wetland? } \\
\text { - Are livestock using the wetland? }\end{array}$ \\
\hline & Provision of fibre & $\begin{array}{l}\text { Timber for building, } \\
\text { wool for clothing, etc. }\end{array}$ & $\begin{array}{l}\text { Are any natural materials such as wood, fibre, } \\
\text { straw, animal fibre } \\
\text { (wool/hide/sinew/antler/other) taken from the } \\
\text { wetland? }\end{array}$ \\
\hline & Provision of fuel & Fuelwood, peat, etc. & $\begin{array}{l}\text { - Is any material taken from the wetland and } \\
\text { used as fuel for domestic or other uses? }\end{array}$ \\
\hline & $\begin{array}{l}\text { Provision of genetic } \\
\text { resources }\end{array}$ & $\begin{array}{l}\text { Rare breeds used for } \\
\text { crop/stock breeding, } \\
\text { etc. }\end{array}$ & $\begin{array}{l}\text { - Are any native or rare strains of plants and } \\
\text { animals, wild and domesticated, which could } \\
\text { contribute genetic diversity for human uses } \\
\text { (for instance for drug manufacture, improving } \\
\text { resilience of domestic animals and plants, } \\
\text { horticultural trade, etc.) }\end{array}$ \\
\hline & $\begin{array}{l}\text { Provision of natural } \\
\text { medicines and } \\
\text { pharmaceuticals }\end{array}$ & $\begin{array}{l}\text { Plants used as } \\
\text { traditional medicines, } \\
\text { etc. }\end{array}$ & $\begin{array}{l}\text { - Are there any plants, animals or their parts } \\
\text { derived from the wetland which are harvested } \\
\text { and used for their medicinal properties? }\end{array}$ \\
\hline & $\begin{array}{l}\text { Provision of ornamental } \\
\text { resources }\end{array}$ & $\begin{array}{l}\text { Collection of shells, } \\
\text { flowers, etc. }\end{array}$ & $\begin{array}{l}\text { - Are there any plants, animals or their parts are } \\
\text { derived from wetland that are collected and } \\
\text { used/sold for their ornamental properties? }\end{array}$ \\
\hline & $\begin{array}{l}\text { Clay, mineral, aggregate } \\
\text { harvesting }\end{array}$ & $\begin{array}{l}\text { Sand and gravel } \\
\text { extracted for building } \\
\text { use, clay extracted for } \\
\text { brick-making, etc. }\end{array}$ & $\begin{array}{l}\text { - What substances are extracted or dug up from } \\
\text { the wetland for construction or other human } \\
\text { uses? }\end{array}$ \\
\hline & Waste disposal & $\begin{array}{l}\text { Dumping of solid waste, } \\
\text { discharge of waste } \\
\text { water, etc. }\end{array}$ & $\begin{array}{l}\text { - Does the wetland provide a location for the } \\
\text { disposal of liquid, solid or other waste } \\
\text { materials? }\end{array}$ \\
\hline & $\begin{array}{l}\text { Energy harvesting from } \\
\text { natural air and water } \\
\text { flows }\end{array}$ & $\begin{array}{l}\text { Water wheels driven by } \\
\text { flowing water, } \\
\text { windmills driven by the } \\
\text { wind, etc. }\end{array}$ & $\begin{array}{l}\text { - Are any technologies (water wheels, wind } \\
\text { turbines, etc.) used to capture natural flows of } \\
\text { energy through or across the wetland? }\end{array}$ \\
\hline 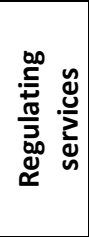 & Air quality regulation & $\begin{array}{l}\text { Removal of airborne } \\
\text { particles from the } \\
\text { exhaust of cars, } \\
\text { chimneys of industry, } \\
\text { dust from agricultural } \\
\text { land, etc. }\end{array}$ & $\begin{array}{l}\text { - Is there a source for airborne pollutants? } \\
\text { - Does the wetland habitat structure help to } \\
\text { settle out airborne pollutants? } \\
\text { - Does the state of the wetland make it a source } \\
\text { of air pollutants (microbial, particulate or } \\
\text { chemical)? }\end{array}$ \\
\hline
\end{tabular}

McInnes, R.J., Everard, M. (2017) Rapid Assessment of Wetland Ecosystem Services (RAWES): An example from Colombo, Sri Lanka. Ecosystem Services. DOI: 10.1016/j.ecoser.2017.03.024 


\begin{tabular}{|c|c|c|}
\hline Local climate regulation & $\begin{array}{l}\text { Regulation of the local } \\
\text { microclimate, through } \\
\text { shading, reducing air } \\
\text { temperature, etc. }\end{array}$ & $\begin{array}{l}\text { Does the wetland habitat structure provide } \\
\text { shade for humans? } \\
\text { Does the wetland have areas of standing water } \\
\text { with or without vegetation that will be } \\
\text { generating evapotranspiration and } \\
\text { consequently reducing air temperatures? }\end{array}$ \\
\hline $\begin{array}{l}\text { Global climate } \\
\text { regulation }\end{array}$ & $\begin{array}{l}\text { Regulation of the global } \\
\text { climate through control } \\
\text { in greenhouse gas } \\
\text { emissions, the } \\
\text { sequestration of } \\
\text { carbon, etc. }\end{array}$ & $\begin{array}{l}\text { - Does the wetland store and/or sequester } \\
\text { carbon? } \\
\text { - Does this balance with generation of methane } \\
\text { and other greenhouse gases? }\end{array}$ \\
\hline Water regulation & $\begin{array}{l}\text { Regulation of flows of } \\
\text { surface water during } \\
\text { high and low flows, } \\
\text { regulation of recharge } \\
\text { of groundwater, etc. }\end{array}$ & $\begin{array}{l}\text { Do the topography, permeability and } \\
\text { roughness of the wetland enable it to store } \\
\text { water during high rainfall/discharge and top } \\
\text { slowly release it back to surface waters or to } \\
\text { groundwater? } \\
\text { Does the wetland regulate discharges during } \\
\text { dry periods to buffer low flows during dry } \\
\text { weather? }\end{array}$ \\
\hline Flood hazard regulation & $\begin{array}{l}\text { Regulation and storage } \\
\text { of flood water, } \\
\text { regulation of intense } \\
\text { rainfall events, etc. }\end{array}$ & $\begin{array}{l}\text { Does the wetland regulate, store and retain } \\
\text { floodwaters? } \\
\text { Does the wetland store rainfall and surface } \\
\text { water that might contribute to flooding and } \\
\text { damage to property or ecosystems } \\
\text { downstream? }\end{array}$ \\
\hline $\begin{array}{l}\text { Storm hazard } \\
\text { regulation }\end{array}$ & $\begin{array}{l}\text { Regulation of tidal or } \\
\text { storm surges, } \\
\text { regulation of extreme } \\
\text { winds, etc. }\end{array}$ & $\begin{array}{l}\text { Does the complexity of habitat, particularly } \\
\text { trees, tall reeds and other vegetation and } \\
\text { surface topography, absorb energy from } \\
\text { extreme events such as storms and waves that } \\
\text { might otherwise damage property or adjacent } \\
\text { ecosystems? }\end{array}$ \\
\hline Pest regulation & $\begin{array}{l}\text { Control of pest species } \\
\text { such as mosquitoes, } \\
\text { rats, flies, etc. }\end{array}$ & $\begin{array}{l}\text { Do natural predation and other ecological } \\
\text { processes in the wetland regulate and control } \\
\text { pest organisms? } \\
\text { - Is the wetland a source of pests (for example } \\
\text { rats thriving in dirty water systems)? }\end{array}$ \\
\hline $\begin{array}{l}\text { Regulation of human } \\
\text { diseases }\end{array}$ & $\begin{array}{l}\text { Presence of species } \\
\text { that control the species } \\
\text { (vectors) that transmit } \\
\text { human diseases such as } \\
\text { malaria, West Nile } \\
\text { fever, dengue fever, } \\
\text { Zika virus, leptospirosis, } \\
\text { schistosomiasis, etc. }\end{array}$ & $\begin{array}{l}\text { - Do natural predation and other ecological } \\
\text { processes in the wetland regulate organisms } \\
\text { that may cause human diseases? } \\
\text { - Are faecal deposits, bacteria or other } \\
\text { potentially pathogenic microbes immobilised } \\
\text { by processes in the wetland? } \\
\text { - Is the condition of the wetland contributing to } \\
\text { the negative spread of populations of disease } \\
\text { vectors (such as mosquitoes)? }\end{array}$ \\
\hline $\begin{array}{l}\text { Regulation of diseases } \\
\text { affecting livestock }\end{array}$ & $\begin{array}{l}\text { Presence of species } \\
\text { that control the species } \\
\text { (vectors) that transmit } \\
\text { diseases to livestock } \\
\text { such as leptospirosis, } \\
\text { schistosomiasis, duck } \\
\text { virus enteritis, highly } \\
\text { pathogenic avian } \\
\text { influenza, tick-borne } \\
\text { diseases, etc. }\end{array}$ & $\begin{array}{l}\text { - Do natural predation and other ecological } \\
\text { processes in the wetland regulate organisms } \\
\text { that may cause diseases in livestock? } \\
\text { - Are faecal deposits, bacteria or other } \\
\text { potentially pathogenic microbes immobilised } \\
\text { by processes in the wetland? } \\
\text { - Is the condition of the wetland contributing to } \\
\text { the negative spread of populations of disease } \\
\text { vectors (such as mosquitoes or snails)? }\end{array}$ \\
\hline Erosion regulation & $\begin{array}{l}\text { Regulation of energy } \\
\text { environment to reduce } \\
\text { risk of erosion, } \\
\text { presence of dense } \\
\text { vegetation protecting } \\
\text { soils, etc. }\end{array}$ & $\begin{array}{l}\text { - Does the wetland vegetation provide } \\
\text { protection from erosion for the soils? } \\
\text { - Are there any signs of erosion, such as bare } \\
\text { earth, in the wetland? }\end{array}$ \\
\hline
\end{tabular}

McInnes, R.J., Everard, M. (2017) Rapid Assessment of Wetland Ecosystem Services (RAWES): An example from Colombo, Sri Lanka. Ecosystem Services. DOI: 10.1016/j.ecoser.2017.03.024 


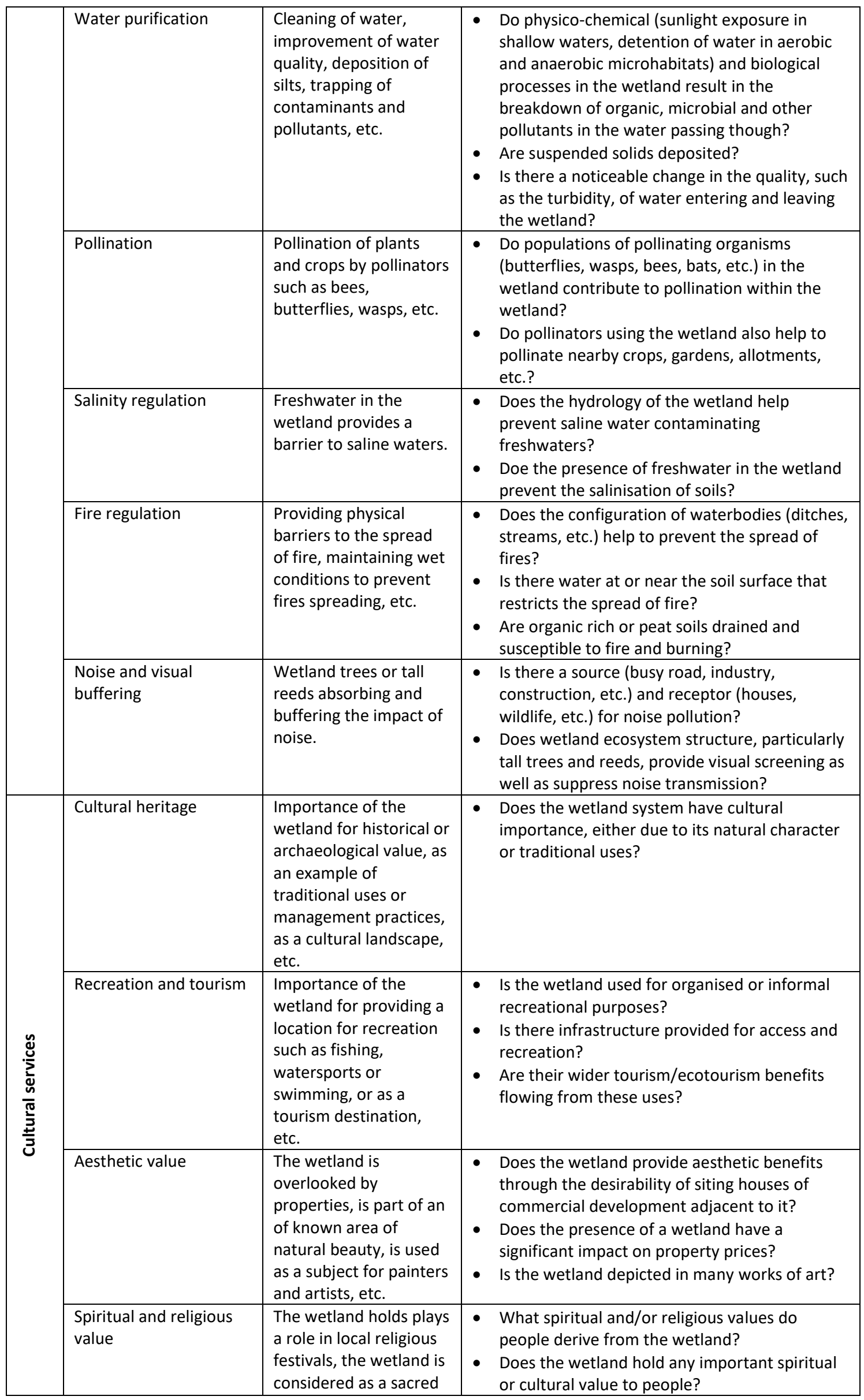

McInnes, R.J., Everard, M. (2017) Rapid Assessment of Wetland Ecosystem Services (RAWES): An example from Colombo, Sri Lanka. Ecosystem Services. DOI: 10.1016/j.ecoser.2017.03.024 


\begin{tabular}{|c|c|c|c|}
\hline & & $\begin{array}{l}\text { site, the wetland forms } \\
\text { part of a traditional } \\
\text { belief system, etc. }\end{array}$ & $\begin{array}{l}\text { - Does the wetland play any part in traditional } \\
\text { religious ceremonies? } \\
\text { - Are there any traditional wetland management } \\
\text { practices (such as the timing of planting and } \\
\text { cropping of rice to Buddhist or other traditions } \\
\text { and teachings) associated with the wetland? }\end{array}$ \\
\hline & Inspirational value & $\begin{array}{l}\text { Presence of local myths } \\
\text { or stories relating to } \\
\text { the wetland, traditional } \\
\text { oral or written histories } \\
\text { about the wetland or } \\
\text { wetland animals, } \\
\text { creation of different art } \\
\text { forms associated with } \\
\text { the wetland, } \\
\text { development of distinct } \\
\text { architecture based on } \\
\text { the wetland, etc. }\end{array}$ & $\begin{array}{l}\text { - Are there any particular myths or other folklore } \\
\text { associated with the wetland? } \\
\text { - Do any wetland animals appear or are featured } \\
\text { in local stories and myths? } \\
\text { - } \text { moes the wetland inspire people to create } \\
\text { - Have particularly ways of designing and } \\
\text { building developed which reflect the wetland? }\end{array}$ \\
\hline & Social relations & $\begin{array}{l}\text { Presence of fishing, } \\
\text { grazing or cropping } \\
\text { communities which } \\
\text { have developed within } \\
\text { and around the } \\
\text { wetland. }\end{array}$ & $\begin{array}{l}\text { - Have communities formed around the wetland } \\
\text { and its uses, including for example fishing } \\
\text { (subsistence, commercial and recreational), } \\
\text { cropping or stock management, walking and } \\
\text { jogging, birdwatching and photography, etc? }\end{array}$ \\
\hline & $\begin{array}{l}\text { Educational and } \\
\text { research }\end{array}$ & $\begin{array}{l}\text { Use of the wetland by } \\
\text { local school children for } \\
\text { education, site of long- } \\
\text { term research and } \\
\text { monitoring, site visited } \\
\text { by organised } \\
\text { educational study } \\
\text { tours, etc. }\end{array}$ & $\begin{array}{l}\text { - Is the wetland used for any educational } \\
\text { purposes, organised or informal, ranging from } \\
\text { school-level visits to university research and } \\
\text { teaching? } \\
\text { - Are there any public awareness or educational } \\
\text { materials present? }\end{array}$ \\
\hline & Soil formation & $\begin{array}{l}\text { Deposition of sediment, } \\
\text { accumulation of organic } \\
\text { matter, etc. }\end{array}$ & $\begin{array}{l}\text { - Do accretion processes (both sedimentation of } \\
\text { mineral material and the build up of organic } \\
\text { material) on the wetland result in the } \\
\text { formation of soils? }\end{array}$ \\
\hline & Primary production & $\begin{array}{l}\text { Presence of primary } \\
\text { producers such as } \\
\text { plants, algae, etc. }\end{array}$ & $\begin{array}{l}\text { - Do photosynthetic processes on the wetland } \\
\text { produce organic matter and store energy in } \\
\text { biochemical form? }\end{array}$ \\
\hline 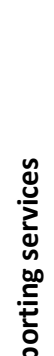 & Nutrient cycling & $\begin{array}{l}\text { Source of nutrients } \\
\text { present from inputs } \\
\text { from agricultural land, } \\
\text { internal cycling of plant } \\
\text { material, inputs of } \\
\text { nutrients from } \\
\text { floodwaters, presence } \\
\text { of fauna to recycling } \\
\text { nutrients, etc. }\end{array}$ & $\begin{array}{l}\text { - Do wetland processes biochemically transform } \\
\text { nutrients (for example } \\
\text { nitrification/denitrification)? } \\
\text { - Are nutrients settled out in particulate forms, } \\
\text { changing the characteristics of water passing } \\
\text { through the system? } \\
\text { - Are there abundant invertebrates and } \\
\text { detritivores that are decomposing and cycling } \\
\text { organic material? }\end{array}$ \\
\hline 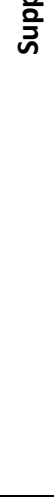 & Water recycling & $\begin{array}{l}\text { Presence of wetland } \\
\text { vegetation and open } \\
\text { water result in } \\
\text { evapotranspiration and } \\
\text { local recycling of water, } \\
\text { relatively closed } \\
\text { canopies and low } \\
\text { exposure to winds } \\
\text { retains water in local } \\
\text { cycles, sandy or coarse } \\
\text { substrates allow } \\
\text { exchange with } \\
\text { groundwaters, etc. }\end{array}$ & $\begin{array}{l}\text { - Does the structure of the wetland retain water } \\
\text { in tight cycles (for example recapture of vapour } \\
\text { produced by evapotranspiration)? } \\
\text { - Does the wetland enable exchanges with } \\
\text { groundwater (either discharge or recharge)? }\end{array}$ \\
\hline
\end{tabular}

McInnes, R.J., Everard, M. (2017) Rapid Assessment of Wetland Ecosystem Services (RAWES): An example from Colombo, Sri Lanka. Ecosystem Services. DOI: 10.1016/j.ecoser.2017.03.024 


\begin{tabular}{|l|l|l|l|}
\hline Provision of habitat & $\begin{array}{l}\text { Presence of locally } \\
\text { important habitats and } \\
\text { species, presence of } \\
\text { species and habitats of } \\
\text { conservation concern, } \\
\text { etc. }\end{array}$ & $\begin{array}{l}\text { - } \\
\text { eoes the wetland support a diversity of locally } \\
\text { represtative biodiversity (plants and } \\
\text { animals)? }\end{array}$ \\
& $\begin{array}{l}\text { Does the wetland support species which } \\
\text { humans consider of conservation concern or as } \\
\text { charismatic interests? }\end{array}$ \\
\hline
\end{tabular}

The assessment of significance is based on consideration of multiple criteria and can vary from site to site. Assessors are required to consider several factors including the quality of the evidence and indicators observed, the number or range of beneficiaries, the uniqueness of the service being provided, whether the service is important for compliance with any regulations or standards and the views of stakeholders consulted. Often there is not a single or definitive outcome and as a consequence the two assessors are encouraged to have a clear dialogue, wherever possible adopt a participatory approach with stakeholders and to record the results of their deliberations.

The RAWES approach also seeks to link the service to beneficiaries. For each ecosystem service, an assessment is made as to the scale at which the benefits accrue. An initial three-point scale is provided but this can be modified to the specific assessment context, for instance if the assessment is considering a finite entity such as a county or metropolitan region. The assessors are trained to apply their local knowledge within the consistent framework provided by the RAWES approach and to make best professional judgements on the scale of the benefits being provided by the wetland. The three scales of benefit considered are described below. However this scale can be refined and modified for the local context (see section 3.2 below).

- Local benefits: Those experienced by individuals, households or communities living and working in the immediate vicinity of the wetland.

- Regional benefits: Those delivered to individuals, households or communities living and working in the wider catchment of the wetland.

- Global benefits: Those that extend beyond national boundaries.

The outputs from applying the RAWES approach can be used to inform subsequent quantitative assessments of targeted ecosystem services, by effectively providing an initial screening, or in more general local or national policy frameworks and decision-making process such as environmental impact assessments.

\section{Implementing the RAWES approach in Colombo, Sri Lanka}

\subsection{The wetlands of Colombo}

Wetlands in Sri Lanka, both natural and man-made, have been at the centre of civilisation across the island for more than two thousand years (Zon, 2004) and continue to provide a range of critical benefits to society today (Sellamuttu et al., 2011). The capital city, Colombo, is subject to a rapid pace of development which is leading to wetland loss and degradation. Between 1981 and 2008, in some areas of the city, $43 \%$ of former paddy lands have been converted to non-wetland (Hettiarachchi et al., 2014a) and for protected areas, such as Kolonnawa Marsh, the rate of conversion may be as high as 65\% over a similar period (Samarasinghe and Dayawansa, 2013). This conversion and degradation of the city's wetlands, driven rapid rates of urbanisation (Hettiarachchi et al., 2014a), has a significant impact on the flows of benefits, the resilience of the city and the wellbeing of citizens (Hettiarachchi et al. 2014b).

Wetland loss and degradation in Colombo has proceeded at pace despite knowledge of the multiple benefits these ecosystems provide. Published studies have demonstrated diverse elements of their 
multiple values, including providing water for domestic purposes (Samarasinghe and Dayawansa, 2013); for bathing and washing (Mahanama, 1998); producing food which both supplements household incomes and contributes to family nutrition (Mohri et al., 2013); providing wood fuel for cooking (Emerton and Kekulandala, 2003); supplying materials for the construction of fish traps, mats and handicrafts (Wijerayaratne, 2000); storing floodwaters and attenuating flooding (Hettiarachchi, 2008; Hettiarachchi et al., 2014b); reducing thermal discomfort and mitigating the urban heat island effect (Emmanuel, 2005; Emmanuel and Johansson, 2006); improving water quality (Jayaweera et al., 2008; Kularatne et al, 2009); affording recreational and tourism opportunities (Marawila \& Thibbotuwawa, 2010); and providing land for the community and for religious activities (Wattage \& Mardle, 2005).

Despite the increasing knowledge and understanding of the benefits that the wetlands of the Colombo Metropolitan Region (CMR) provide, a limited number of studies have been undertaken to understand fully the interconnected range of ecosystem services, the distribution of benefits and the societal relevance of wetland protection, or, conversely, wetland loss. The RAWES field assessment of ecosystem services presented herein forms part of a larger World Bank funded Metro Colombo Urban Development Project which developed a wetland management strategy for the CMR (Mclnnes et al. 2016c).

\subsection{Implementation of RAWES approach}

The field assessment of ecosystem services was conducted at a total of 62 different wetland locations ${ }^{1}$ (Figure 1). Based on a desk study and initial field reconnaissance, these were considered to represent a broad cross section of the different types of wetlands found within the CMR, including: active paddy lands; wooded marshes; open water habitats; traditional tanks; and abandoned paddies. In order to allow validation and interpretation of the results, the field sites selected also represented areas subject to field investigations conducted across the other wetland management strategy project disciplines, such as ecological surveys, hydrological modelling, soil sampling and water quality analysis (Mclnnes et al. 2016b). The selection of field sites further considered the metabolism and urban dynamics of Colombo. To achieve this, initial reconnaissance by team members visited different parts of the city. In addition, local experts in both urban and wetland management were consulted to ensure that due consideration was given to selecting sites in areas of different population densities, industrial, residential or business land-use characteristics, isolated sites and wetland sites which are part of the more contiguous hydrological network.

The field assessors worked for a local non-governmental organisation. Individual assessors were selected based on their track record of working with communities in and around the wetlands of Colombo and their formal academic qualifications in environmental-related sciences. The assessors were trained by the authors and quality control was maintained through repeat assessments and continuous dialogue between the field assessors and the international experts who had applied the method elsewhere (Harrington and McInnes, 2009; McInnes et al. 2013; Everard et al. 2016).

Assessors worked in pairs in order to facilitate discussion and to cross-correlate observations, to provide a further level of quality assurance and to address health and safety concerns. A global positioning system (GPS) was used to locate the sites and a minimum of one photograph was collected for each location. Data were collected on standardised field sheets and transferred to Excel spreadsheets.

\footnotetext{
${ }^{1}$ Note: The numbering of the field sites extends beyond 62 as some sites were rejected due to data inadequacies or site access issues.
}

McInnes, R.J., Everard, M. (2017) Rapid Assessment of Wetland Ecosystem Services (RAWES): An example from Colombo, Sri Lanka. Ecosystem Services. DOI: 10.1016/j.ecoser.2017.03.024 
Figure 1. Locations of field assessments of ecosystem services, Colombo Metropolitan Region. (Note: Wetland areas, including drainage channels, shown in grey; $\Delta$ field assessment sites; short dashed line marks limit of study area; long dashed line marks the approximate boundary between tidal and non-tidally influenced wetlands).

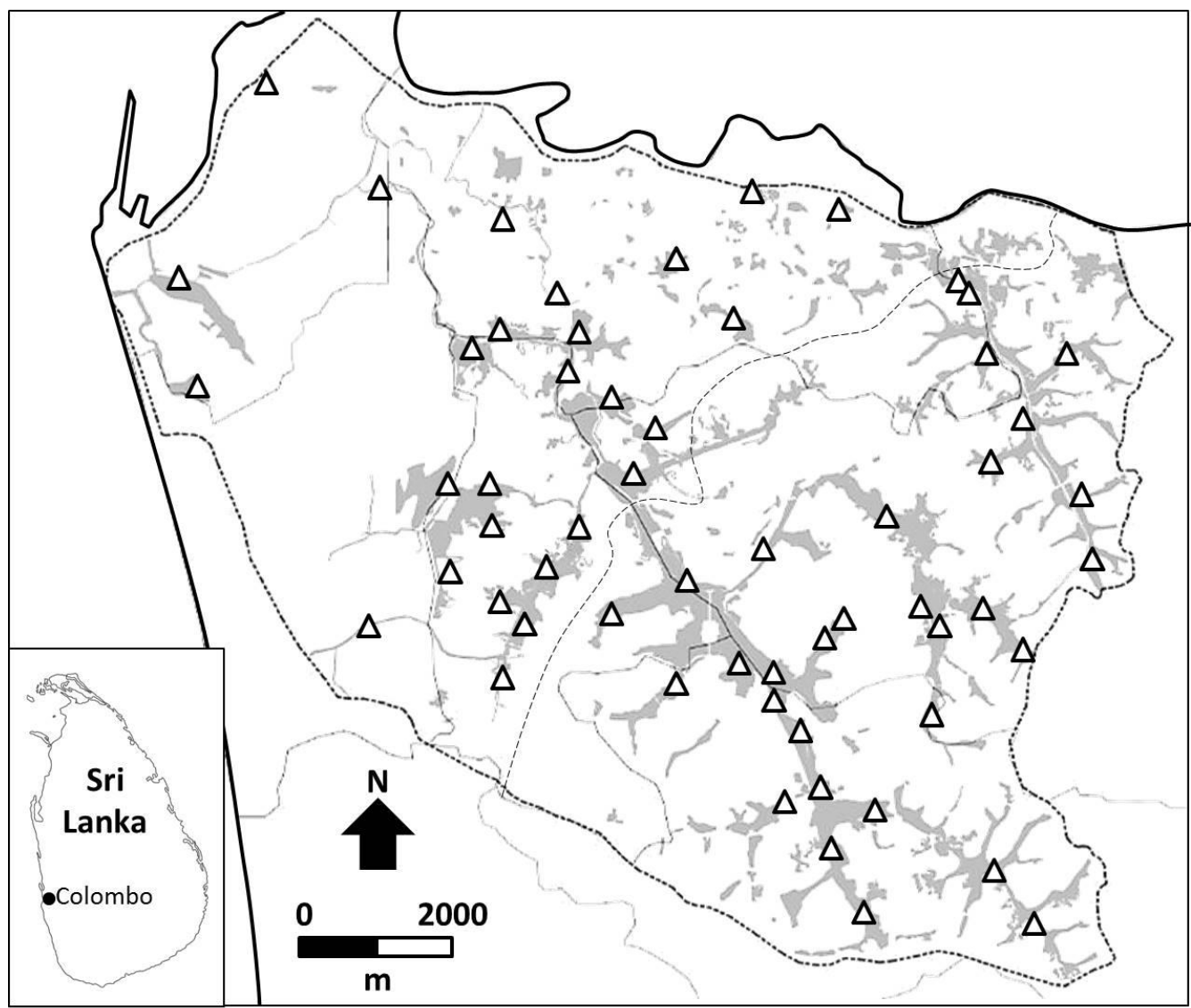

\subsection{Data analysis and manipulation}

For the purpose of data manipulation, analysis, statistical testing and presentation, the relative scale was converted into a nominal, non-linear numerical scale where the following values were assigned to the various categories:

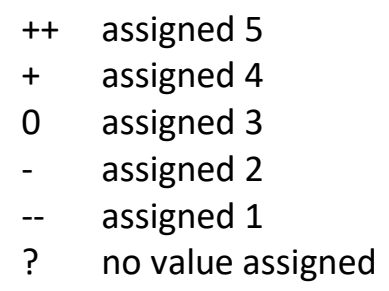

The conversion of qualitative data (++, $0,--$ for instance) into a 'normalized' dimensionless numerical index for analytical purposes has been utilised elsewhere (see van den Bergh and van Veen-Groot, 2001) and such an approach is used widely in hydrogeomorphic (HGM) functional assessments of wetlands in the United States where non-linear indices from zero to 1.00 are estimated on "best professional judgement" (Cole 2006). However, it is recognised that the construction of an index between $1(--)$ and $5(++)$ establishes for each ecosystem service a non-comparable variable which, whilst possessing utility for illustrating issues, there are no underlying rules for weighting and aggregating the data on the basis of specific scientific relationships (Ebert and Welsch, 2004) so 
outcomes of subsequent analyses should be regarded as illustrative only given the limitations associated with manipulating nominal data and treated with a degree of caution.

During preparatory work and the field training of assessors, it became apparent that, in the context of developing a wetland management strategy for the $C M R$, that there would be value in refining the scale at which benefits accrue. Whilst the assessments were undertaken on individual sites, attempts were made to ensure that the assessment of individual ecosystem services considered clearly who would benefit. For instance, genetic resources represented by nationally important rice species; cultural heritage of national importance; water regulation which provided city-wide scale benefits; or recreation and tourism which benefits the city. Therefore, the assessment of the scale of benefit within the context of CMR was modified from an initial three-point scale in order to highlight the benefits to both the wider city of Colombo and within a national context. Consequently a five point scale was applied to assessing the scale at which benefits accrue:

- Local benefits: Those experienced by individuals, households or communities living and working in the immediate vicinity of the wetland.

- City benefits: Those delivered to individuals, households or communities living and working in the wider city of Colombo.

- Regional benefits: Those delivered to individuals, households or communities living and working in the wider catchment of the wetland.

- National benefits: Those delivered individuals, households or communities living and working in the areas beyond the wider catchment but within Sri Lanka.

- Global benefits: Those that extend beyond national boundaries.

\section{Results}

\subsection{Characterisation of field assessment sites}

Based on the hydrological modelling conducted as part of the larger study (Mclnnes et al., 2016c), a distinction was made between wetland areas that are influenced by tidal water level fluctuations ( $n=35 ; 56.5 \%$ of field assessment sites) and those that are beyond the physical influence of tides $(n=27 ; 43.5 \%)$ (Figure 1). Within the tidal area, salinity broadly increases towards the coast and along the main surface water carriers in the drainage system. None of the field assessment sites were located in areas characterised by relatively high levels of salinity due to the lack of wetland areas in these densely built-up locations. Of the tidally influenced sites, fifteen $(n=15 ; 24.2 \%)$ of field sites were characterised by 'medium salinity' ( 300 to $600 \mu \mathrm{S} / \mathrm{cm}$ ) and twenty $(n=20 ; 32.3 \%)$ were considered to be of 'low salinity' $(<300 \mu \mathrm{S} / \mathrm{cm})$. All of the non-tidal sites were observed to fall into the 'low salinity' category.

The non-tidal sites were predominantly characterised by active or former (abandoned) paddy lands with low herb vegetation, sometimes with peripheral trees or woodland. The 'low salinity' tidal sites were characteristically wooded, either in association with open water (usually a channel) or a combination of herb layers. The 'medium salinity' tidal sites were mainly characterised by open water wetlands, often in association with woodland.

\subsection{Ecosystem services recorded}

Twenty-three (65.7\%) of all the services were recorded at every field site (site=100\%) (Table 2). Four ecosystem services $(11.4 \%)$ were recorded at 61 (site=98.4\%) of the field sites and six $(17.1 \%)$ were recorded at 60 (site $=96.8 \%$ ) of the field sites. Where an ecosystem service was not assigned a value, it was due to the need for further information in order to verify the existence of the service. 
Table 2. Count data for the frequency of the ecosystem service scores.

\begin{tabular}{|c|c|c|c|c|c|c|}
\hline Ecosystem service & $\mathbf{n}$ & ++ & + & 0 & - & - \\
\hline Fresh water & 60 & 5 & 25 & 26 & 3 & 1 \\
\hline Food & 60 & 11 & 43 & 6 & 0 & 0 \\
\hline Fibre and fuel & 60 & 1 & 14 & 45 & 0 & 0 \\
\hline Genetic resources & 62 & 3 & 23 & 36 & 0 & 0 \\
\hline Biochemicals, natural medicines, pharmaceuticals & 62 & 3 & 46 & 12 & 1 & 0 \\
\hline Ornamental resources & 62 & 3 & 5 & 54 & 0 & 0 \\
\hline Clay, mineral, aggregate harvesting & 62 & 0 & 2 & 60 & 0 & 0 \\
\hline Waste disposal & 62 & 1 & 28 & 25 & 5 & 3 \\
\hline Energy harvesting from natural air and water flows & 62 & 0 & 1 & 61 & 0 & 0 \\
\hline Air quality regulation & 60 & 9 & 40 & 7 & 4 & 0 \\
\hline Climate regulation - local & 62 & 8 & 48 & 6 & 0 & 0 \\
\hline Climate regulation - global & 62 & 15 & 17 & 29 & 1 & 0 \\
\hline Water regulation & 62 & 16 & 35 & 10 & 1 & 0 \\
\hline Natural hazard regulation & 62 & 2 & 23 & 36 & 1 & 0 \\
\hline Pest regulation & 61 & 4 & 45 & 9 & 3 & 0 \\
\hline Disease regulation - human & 61 & 2 & 25 & 33 & 0 & 1 \\
\hline Disease regulation - stock & 51 & 0 & 8 & 43 & 0 & 0 \\
\hline Erosion regulation & 62 & 8 & 27 & 27 & 0 & 0 \\
\hline Water purification and waste treatment & 62 & 6 & 30 & 23 & 3 & 0 \\
\hline Pollination & 62 & 3 & 50 & 7 & 2 & 0 \\
\hline Salinity regulation, fire regulation & 62 & 0 & 19 & 43 & 0 & 0 \\
\hline Noise and visual buffering & 61 & 1 & 36 & 20 & 4 & 0 \\
\hline Cultural heritage & 62 & 2 & 18 & 41 & 0 & 1 \\
\hline Recreation and tourism & 60 & 7 & 17 & 33 & 3 & 0 \\
\hline Aesthetic value & 62 & 4 & 37 & 19 & 1 & 1 \\
\hline Spiritual and religious value & 62 & 3 & 3 & 56 & 0 & 0 \\
\hline Inspiration of art, folklore, architecture, etc. & 60 & 1 & 20 & 39 & 0 & 0 \\
\hline Social relations & 58 & 3 & 33 & 20 & 2 & 0 \\
\hline Educational and research & 62 & 8 & 36 & 18 & 0 & 0 \\
\hline Soil formation & 62 & 6 & 26 & 30 & 0 & 0 \\
\hline Primary production & 62 & 9 & 28 & 23 & 2 & 0 \\
\hline Nutrient cycling & 62 & 8 & 42 & 11 & 1 & 0 \\
\hline Water recycling & 61 & 6 & 29 & 23 & 3 & 0 \\
\hline Photosynthesis & 62 & 14 & 25 & 23 & 0 & 0 \\
\hline Provision of habitat & 62 & 27 & 25 & 10 & 0 & 0 \\
\hline
\end{tabular}

Ecosystem services making a significant positive contribution were recorded less frequently than those making a positive contribution (Figure 2). The highest significant positive contribution of any ecosystem service was the provision of habitat $(++=27)$. Water regulation $(++=16)$, global climate regulation $(++=15)$ and photosynthesis $(++=14)$ also made a significant positive contribution. Pollination $(+=50)$ was the most frequently occurring ecosystem service making a positive contribution. Control of local climate $(+=48)$, provision of natural medicines $(+=46)$, regulation of pests $(+=45)$, the provision of food $(+=43)$ and nutrient cycling $(+=42)$ all made a positive contribution at more than two-thirds of all the field sites. Waste disposal (--=3) made the most significant negative contribution. All three of the sites where waste disposal was considered to be a significantly negative service were located in heavily built up areas towards the north-western limit of the study area.

Figure 2 demonstrates the predominance of positive contributions made by the wetlands to human wellbeing. Differences are observed among the four main categories of ecosystem services. The importance of the supporting services, and particularly the provision of habitat, is clearly shown in Figure 2. Food and natural medicines are the most important provisioning services, with fresh water, fibre and fuel, genetic resources and waste disposal also making a positive contribution. The positive contribution of the cultural services varies, educational, social relational and aesthetic 
services scoring highest. However, the spiritual and religious ecosystem services are the least recorded of the cultural services, albeit that all contributions were positive with half of them significantly so. The regulating services provide a broad range of positive contributions with climate regulation, on both a local and global scale; the regulation of water; the moderation of air pollution; importance of wetlands for providing pollination; and the ability of the ecological functioning of wetlands to control pest and regulate diseases are all recorded extensively across the city. However, the regulation of disease in stock is recorded at a relatively lower frequency, potential due to the absence of stock at many of the field sites (see Table 2).

Figure 2. Relative importance of individual ecosystem services from all field assessment sites $(n=62)$ with ' 0 ' score removed. (cross-hatch - -; white -; grey +; black ++).

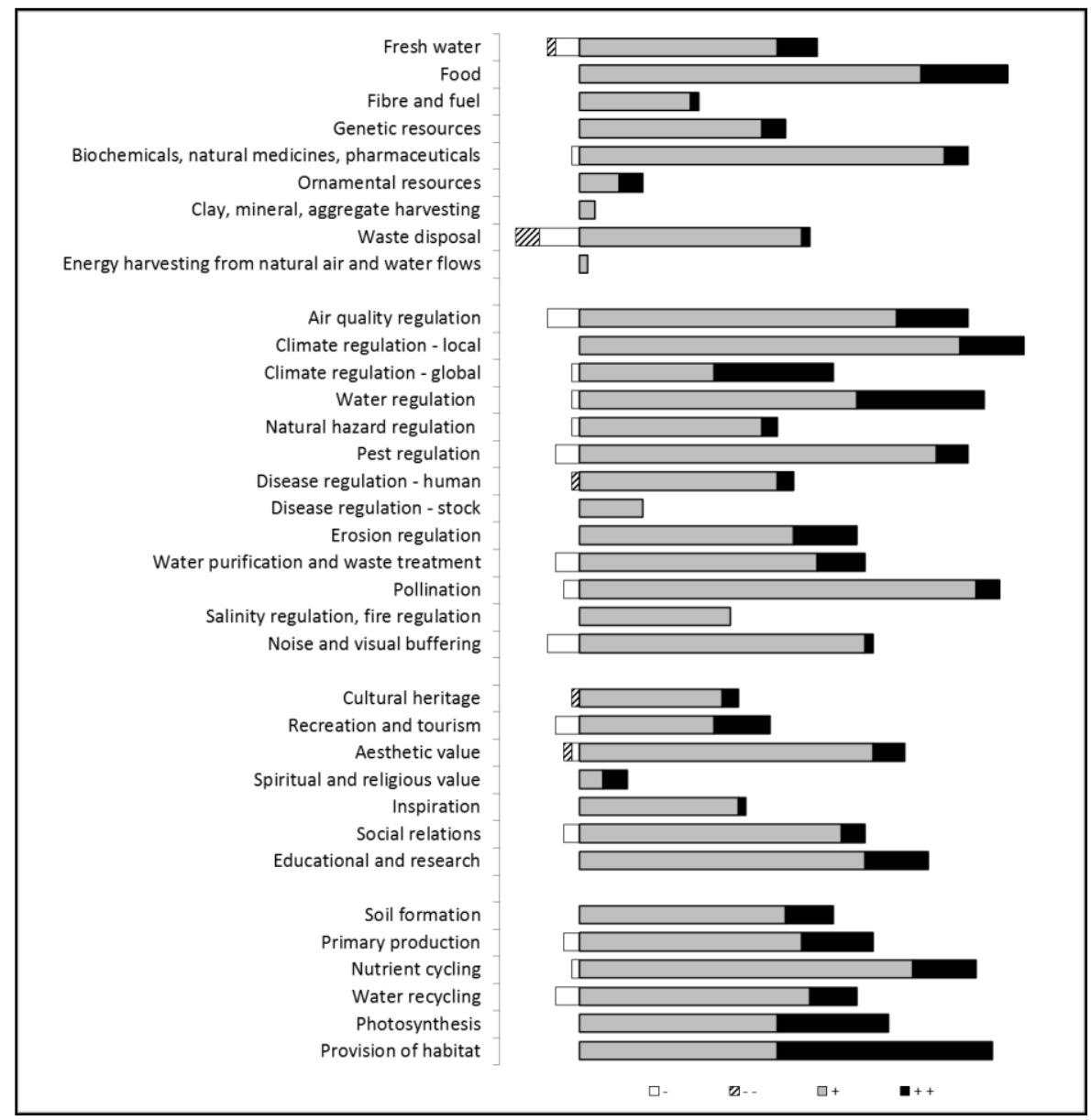

The overall variability in the delivery of positive contributions (++ or +) made by ecosystem services across the 62 field sites was illustrated by plotting the mean score (derived from the non-linear nominal index) for each ecosystem service against the standard deviation (used as a surrogate for variability in the result, i.e. low standard deviation represents abundance of similar scores, high standard deviation represents wider dissimilarity in scores) (Figure 3). The data demonstrate that as the frequency of ++ scores increase the variability also increases suggesting that for these services their significance varies across the sites. Conversely, services with a score tending towards + show greater similarity. For instance, regulation of global climate, provision of habitat and spiritual and religious importance all have a relatively high overall significance but also demonstrates a relatively high variability between + and ++ scores. This outcome is also reflected in Figure 2 which shows a 
relative equal division of + and ++ scores for these services. Whereas regulation of disease in stock and control of salinity and fire show low variability as only + scores were recorded for these services.

Figure 3. Relative significance of benefits (--, - and 0 scores removed) and variability of mean scores for ecosystem services from all field assessment sites $(n=62)$. (Dashed grey lines intersecting the $x$ and $y$-axes represent the mean of the means and standard deviations. Abbreviations: FW fresh water; FD food; FF fibre/fuel; GR genetic resources; PH pharmaceuticals; OR ornamental resources; MN minerals; WD waste disposal; EN energy; AQ air quality; LC local climate; GC global climate; WR water regulation; NH natural hazard; PR pest regulation; DH disease regulation humans; DS disease regulation stock; ER erosion regulation; WP water purification; PL pollination; SP salinity/fire regulation; NV noise/visual buffering; $\mathrm{CH}$ cultural heritage; RT recreation/tourism; AS aesthetics; SR spiritual/religious; IN inspiration; SC social relations; ED education/research; SF soil formation; PP primary production; NC nutrient cycling; WT water recycling; PH photosynthesis; HB provision of habitat).
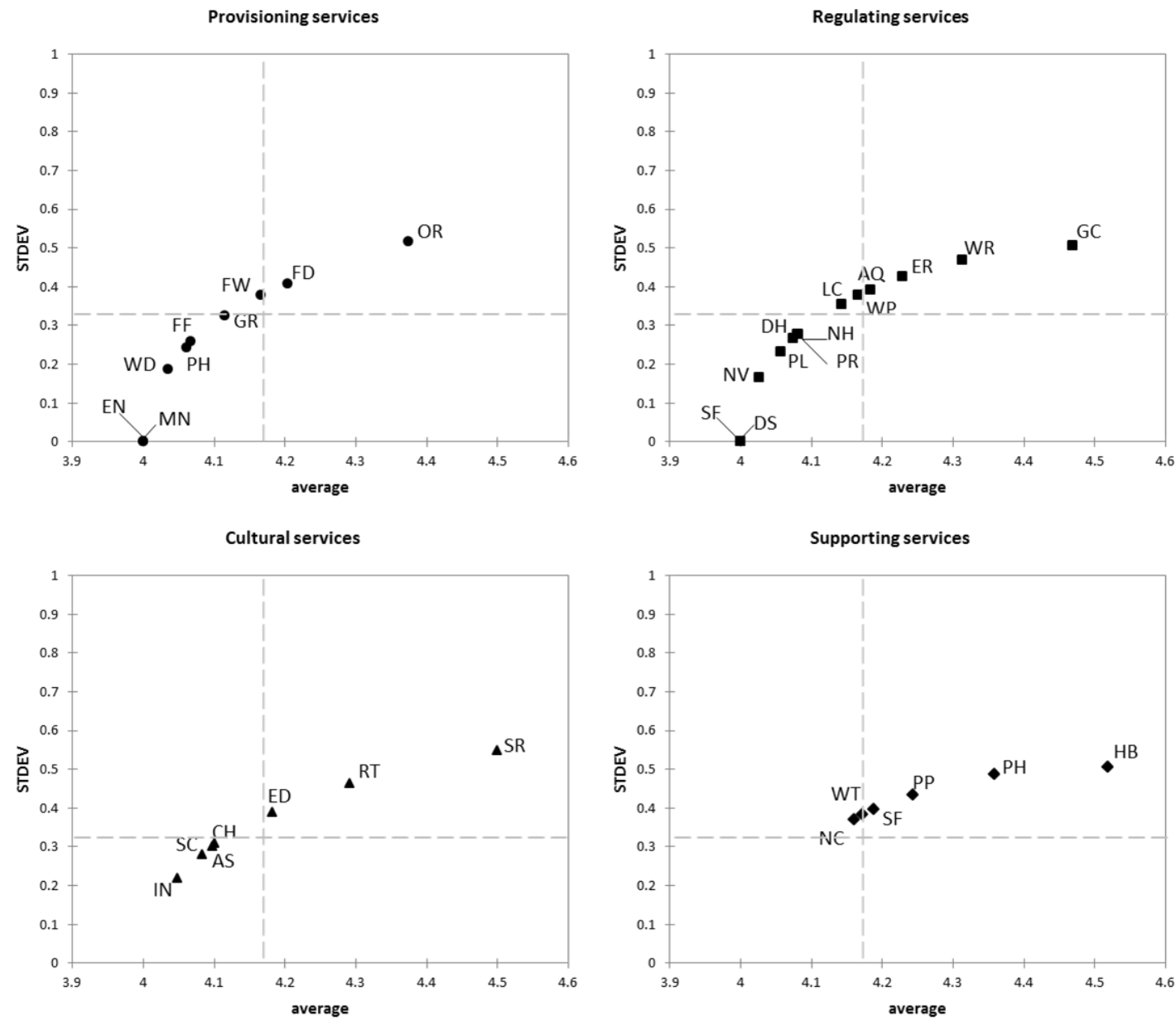

\subsection{Correlation among ecosystem services}

Correlations between individual ecosystem services have been assessed using Pearson's correlation coefficients $(r)$. The majority of relationships were not significant. However, the supporting services are strongly correlated with each other and some other services, perhaps reflecting their significance as a linked set of ecosystem functions underpinning the production of other more directly exploited services. The provision of habitat is significantly correlated with soil formation $(r=0.700, p=<0.0001)$, primary production $(r=0.684, p=<0.0001)$ and photosynthesis $(r=0.720, p=<0.0001)$. Similarly, primary production is correlated with soil formation $(r=0.690, p=<0.0001)$ and photosynthesis $(r=0.777, p=<0.0001)$. Soil formation $(r=0.810, p=<0.0001)$, primary production $(r=0.706, p=<0.0001)$ and provision of habitat $(r=0.690, p=<0.0001)$ are all correlated with the regulating service erosion regulation. Photosynthesis also demonstrated a positive correlation with global climate regulation 
$(r=0.725, p=<0.0001)$, reflecting the role of oxygen-generating plant activity in carbon capture and sequestration.

A positive correlation was observed between disease regulation for humans and pests $(r=0.670$, $p=<0.0001$ ), which is understandable given the commonality of disease vectors and pathways. Several other weaker correlations were observed among the regulating services with erosion regulation being positively correlated with local $(r=0.477, p=<0.0001)$ and global climate $(r=0.506$, $p=<0.0001)$ regulation and water regulation $(r=0.483, p=<0.0001)$. Water regulation was also positively correlated with water purification $(r=0.627, p=<0.0001)$ and pollination $(r=0.424$, $p=<0.0001)$. Spiritual and inspirational value and aesthetics were positively correlated with a range of the regulating services but at a lower level of significance. The provisioning services demonstrated only weak positive correlations with other provisioning services and those from the other three categories. Of the provisioning services, fresh water was most strongly positively correlated with cultural heritage $(r=0.562, p=<0.0001)$ and food provision $(r=0.517, p=<0.0001)$.

\subsection{Classifying sites by ecosystem services}

Agglomerative hierarchical clustering using Euclidean distance has been used to explore whether the correlations observed among services represent common groupings of services provided by certain wetland sites and as to whether it is possible to classify the field sites based on dissimilarities in the ecosystem services (Figure 4).

Figure 4. Dendrogram produced as a result of agglomerative hierarchical clustering of field sites based on their ecosystem services.

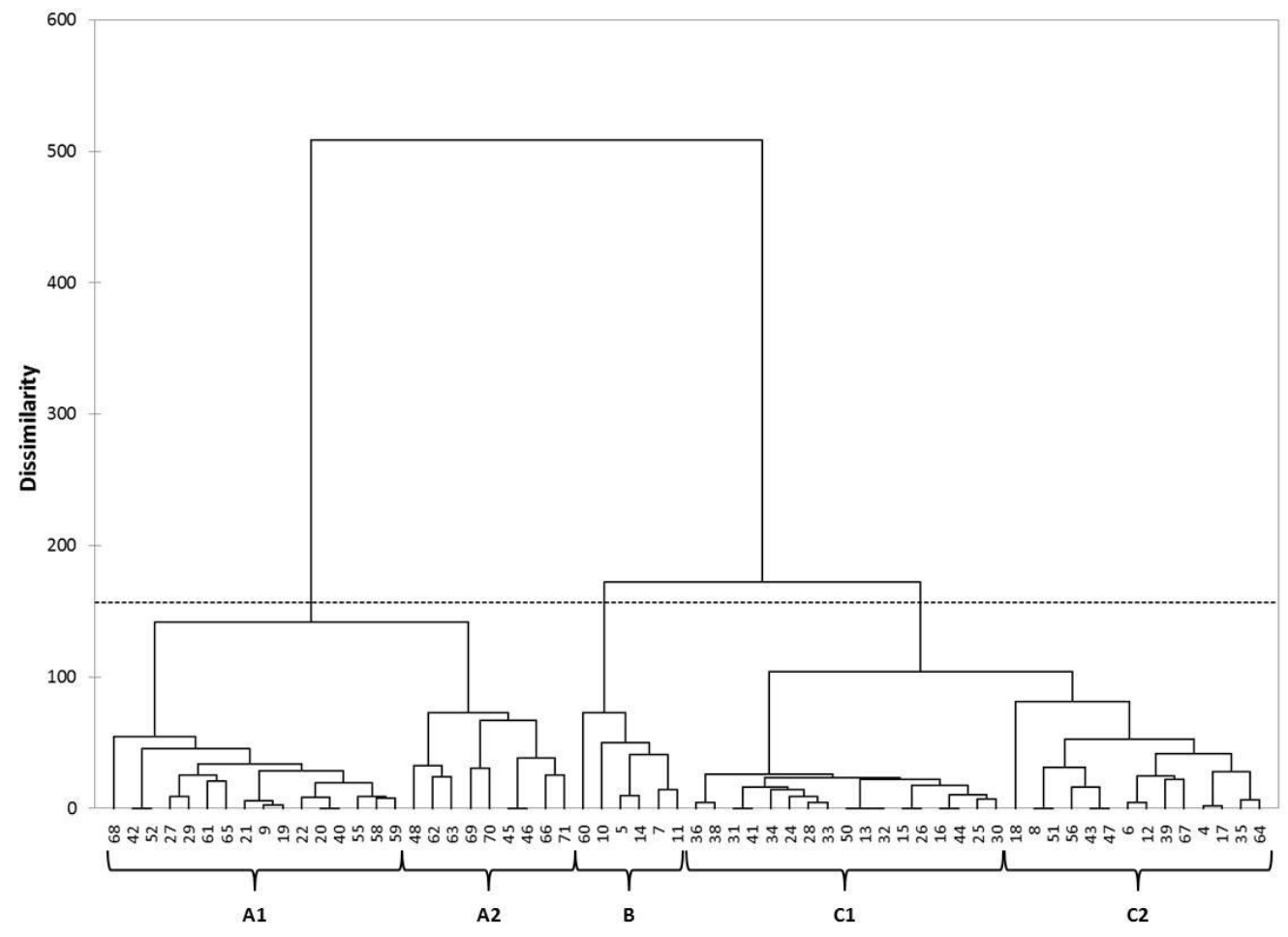

The sites clustered into five classes termed A1, A2, B, C1 and C2 (Figure 4, Table 3). Class B is the smallest cluster $(n=6)$. Cluster $C 1$ contains the largest number of sites $(n=17)$ and there is a high degree of similarity among the sites, as demonstrated by a dissimilarity score of less than 50 . Class C2 ( $n=14)$ has one distinct field site (site 18) and two sub clusters. Cluster A1 contains the second largest number of field sites ( $n=16)$. Cluster $A 2$ contains nine sites $(n=9)$ which can be subdivided into three sub clusters all relatively dissimilar to each other. 
The non-tidal, predominantly paddy and abandoned paddy sites in Class A2 deliver the highest level of ecosystem services whereas class B sites, which are predominantly found in the heavily urbanised tidal areas of the city, provide the lowest level of services (Figure 5). Clusters C1 and C2 represent similar wetland types, including open water, woodland, floating vegetation, tall and low herb, paddy and abandoned paddy, and they deliver the similar levels of ecosystem services. The sites in the A1 cluster deliver similar, but consistently higher, services than $\mathrm{C} 1$ and $\mathrm{C} 2$.

Figure 5. Count of score per service for the five cluster classes.

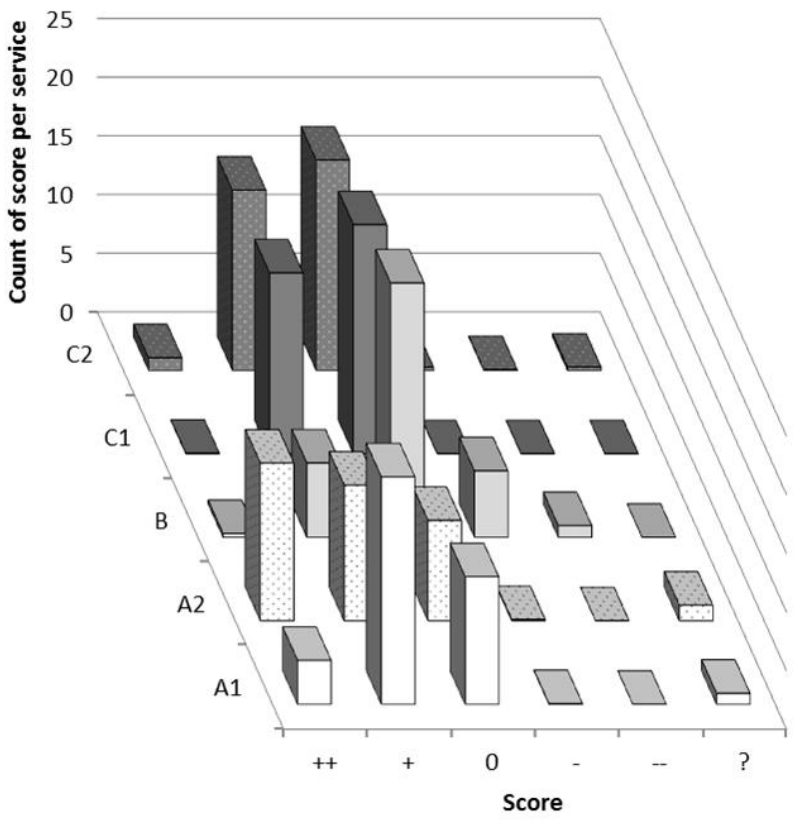

Table 3. Summary description of field sites clusters based one ecosystem services.

\begin{tabular}{|c|c|c|c|c|}
\hline Cluster & Location & Tidal & Wetland types & Description of ecosystem services \\
\hline A1 & $\begin{array}{l}\text { Widespread } \\
\text { across CMR }\end{array}$ & $\begin{array}{l}\text { Low salinity and } \\
\text { non-tidal areas }\end{array}$ & $\begin{array}{l}\text { Open water, woodland, } \\
\text { floating vegetation, tall } \\
\text { herb, paddy and } \\
\text { abandoned paddy }\end{array}$ & $\begin{array}{l}\text { Provisioning services generally score } \\
\text { lower than A2 but similar to C1. } \\
\text { Regulating services are highest for } \\
\text { regulation of global climate and air quality } \\
\text { and consistently higher than C1, C2 and B } \\
\text { across all other regulating services. } \\
\text { Cultural services are highest for } \\
\text { inspiration but similar to all other classes } \\
\text { except A2 which is consistently higher for } \\
\text { cultural services with the exception of } \\
\text { inspiration. } \\
\text { Supporting services have the second } \\
\text { highest average values recorded for all } \\
\text { services. }\end{array}$ \\
\hline A2 & $\begin{array}{l}\text { Central area of } \\
\text { CMR }\end{array}$ & $\begin{array}{l}\text { Predominantly in } \\
\text { non-tidal areas }\end{array}$ & $\begin{array}{l}\text { Predominantly paddy } \\
\text { and abandoned paddy } \\
\text { but with some minor } \\
\text { woodland, low herb } \\
\text { and open water }\end{array}$ & $\begin{array}{l}\text { Consistently deliver the highest level of } \\
\text { ecosystem services across the four major } \\
\text { categories, especially for supporting } \\
\text { services. } \\
\text { Provisioning services are high for food and } \\
\text { water, natural medicines and ornamental } \\
\text { resources } \\
\text { Regulating services score highly for water } \\
\text { regulation (flood control), high water } \\
\text { treatment also good for erosion control, }\end{array}$ \\
\hline
\end{tabular}

McInnes, R.J., Everard, M. (2017) Rapid Assessment of Wetland Ecosystem Services (RAWES): An example from Colombo, Sri Lanka. Ecosystem Services. DOI: 10.1016/j.ecoser.2017.03.024 


\begin{tabular}{|c|c|c|c|c|}
\hline & & & & $\begin{array}{l}\text { pollination and pest regulation } \\
\text { Cultural services are significantly high for } \\
\text { education and also relatively high for } \\
\text { spiritual, recreational, cultural and social } \\
\text { relations. Only low score is recorded for } \\
\text { inspiration. } \\
\text { Supporting services have the highest } \\
\text { average score recorded for all services. }\end{array}$ \\
\hline$B$ & $\begin{array}{l}\text { Heavily } \\
\text { urbanised } \\
\text { northern areas } \\
\text { of CMR }\end{array}$ & $\begin{array}{l}\text { Low and medium } \\
\text { salinity tidal areas }\end{array}$ & $\begin{array}{l}\text { Open water, woodland, } \\
\text { tall and low herb }\end{array}$ & $\begin{array}{l}\text { Provisioning services are scored highest } \\
\text { and most consistently for waste disposal. } \\
\text { Regulating services are scored low for } \\
\text { human disease regulation and erosion } \\
\text { control, but high for natural hazard } \\
\text { regulation and salinity control. } \\
\text { Cultural services have a moderate score } \\
\text { for all services. } \\
\text { Supporting services have low scores for } \\
\text { soil formation, photosynthesis and } \\
\text { provision of habitat. }\end{array}$ \\
\hline C1 & $\begin{array}{l}\text { Widespread } \\
\text { across CMR }\end{array}$ & $\begin{array}{l}\text { Mainly in low and } \\
\text { medium salinity } \\
\text { tidal areas but also } \\
\text { in non-tidal areas }\end{array}$ & $\begin{array}{l}\text { Open water, woodland, } \\
\text { floating vegetation, tall } \\
\text { and low herb and very } \\
\text { occasional paddy }\end{array}$ & $\begin{array}{l}\text { Provisioning services are scored higher } \\
\text { than } C 2 \text { and } B \text { but predominantly lower } \\
\text { than } A 1 \text { and } A 2 \text {. } \\
\text { Regulating services are scored higher than } \\
\text { C2 but predominantly lower than } A 1, A 2 \\
\text { and } B \text {. } \\
\text { Cultural services are scored higher than } \\
\text { C2, except for education, but } \\
\text { predominantly lower than A1 and A2, and } \\
\text { higher than B for recreation and } \\
\text { aesthetics. } \\
\text { Supporting services are scored higher } \\
\text { than } C 2 \text { and B, but the sites provide a } \\
\text { consistently lower level of service than A1 } \\
\text { and } A 2 \text {. }\end{array}$ \\
\hline $\mathrm{C} 2$ & $\begin{array}{l}\text { Widespread } \\
\text { across CMR }\end{array}$ & $\begin{array}{l}\text { Tidal and non-tidal } \\
\text { areas }\end{array}$ & $\begin{array}{l}\text { Open water, woodland, } \\
\text { floating vegetation, tall } \\
\text { and low herb, paddy } \\
\text { and abandoned paddy }\end{array}$ & $\begin{array}{l}\text { Relatively low levels of provisioning } \\
\text { services are provided across the sites } \\
\text { especially for waste disposal and fresh } \\
\text { water. } \\
\text { Regulating services are scored at the } \\
\text { lowest level for these sites. } \\
\text { Cultural services have the lowest mean } \\
\text { scores for cultural heritage, recreation } \\
\text { and aesthetic values. } \\
\text { Supporting services have the lowest } \\
\text { scores for primary production, nutrient } \\
\text { cycling and water recycling. }\end{array}$ \\
\hline
\end{tabular}

Principle component analysis (PCA) using the Pearson correlation has been conducted to investigate and visualise possible relationships among the ecosystem services and to further interpret any possible grouping of sites based on their ecosystem services (Figure 6). The intention of using PCA is not to test the significance of any correlations but rather to display and visualise the data. The five clusters defined in the agglomerative hierarchical cluster analysis can be isolated in the PCA bi-plot, however there is also some commonality across the clusters, especially between classes A1 and A2.

Several individual ecosystem services have been interrogated to assess similarities or differences among the clusters. The role of paddy areas in providing food is clearly observed for cluster A2. The impact of the wetlands providing locations for waste disposal is observed in the heavily urbanised sites comprising cluster B2. However these same sites, many of which have been heavily modified, are also important for reducing flood hazards. The A2 sites provide the largest contribution in terms of recreation and tourism, however there is considerable variation in this service among the sites.

McInnes, R.J., Everard, M. (2017) Rapid Assessment of Wetland Ecosystem Services (RAWES): An example from Colombo, Sri Lanka. Ecosystem Services. DOI: 10.1016/j.ecoser.2017.03.024 
The A2 sites also provided the greatest contribution with regard to the formation of soil and the provision of habitat services, with the B sites providing a significantly lower level of contribution. Overall, the A2 sites consistently provide a larger positive contribution than the other sites, with the $B$ and $C 2$ sites provide the relatively lowest level of benefits.

Figure 6. PCA bi-plot to visualise clustering of field sites and ecosystem services.

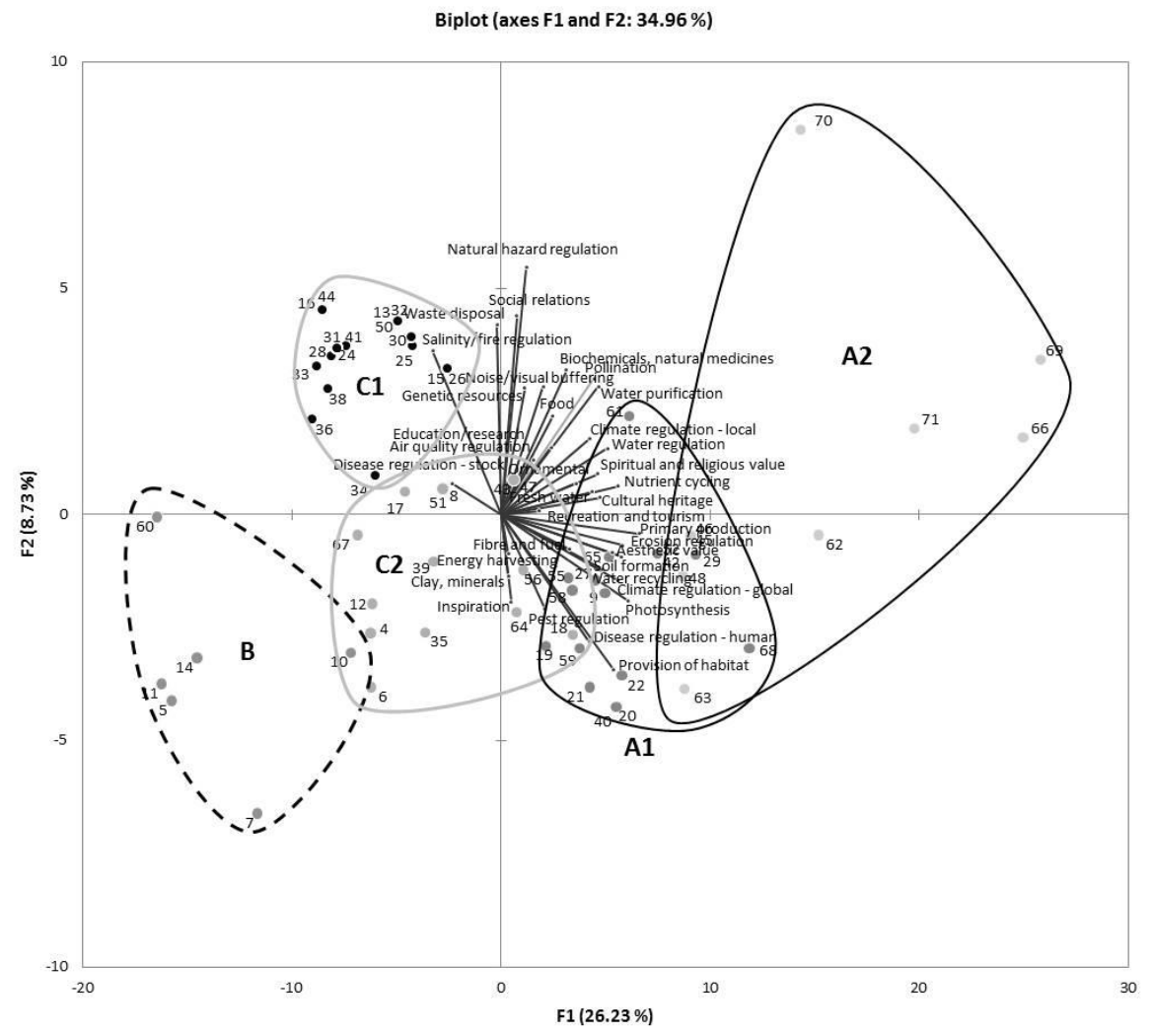

There is an apparent trajectory of change between sites with regard to the significance of the contribution of ecosystem services. The non-tidal A2 sites, which predominantly comprise active or abandoned rice paddies, progress towards $A 1$ sites with increasing levels of abandonment, salinity (which limits the ability to grow rice) and urban pressures and also towards $\mathrm{C} 2$ sites where the tidal influence is low or negligible. Whereas the predominantly tidal $\mathrm{C} 1$ sites progress towards $\mathrm{C} 2$ and $\mathrm{B}$ sites.

\subsection{Scale of benefit}

The benefits derived from the ecosystem services are delivered across a range of scales, from locally in the immediate vicinity of a wetland (soil formation) through regional (food production) and national benefits to those that contribute at a global scale (climate regulation) (Table 4).

The recording of information on the scale of benefit was less comprehensive than for the significance of individual ecosystem services. Often this was due to a lack of direct evidence to link the service to a beneficiary, or because insufficient information had been gained from field indicators or consulting with local stakeholders regarding potential beneficiaries. The ecosystem services assigned a score of ' 0 ' did not have a corresponding scale of benefit. Therefore, the total count for the scale of benefit data is often less than the count of ecosystem service scores (Table 4). For instance, an evaluation of the provision of fresh water was recorded at 60 field sites, but the ' 0 ' score accounted for 26 locations, therefore the scale of benefit was only indicated for 34 sites. Out 
of these 34 sites, the scale of the benefit was only recorded at $31(91.18 \%)$ sites. For several services, there was sufficient information to make a judgement on the scale of the benefit, for instance the provision of ornamental resources, water regulation, noise or visual buffering, cultural heritage or soil formation. The ecosystem services that presented assessors with the greatest difficulty in terms of practical interpretation with regards to the scale at which their benefits are delivered were salinity and fire regulation (84.21\%), genetic resources (84.62\%) and water purification (87.18\%).

Table 4. Scale of benefit of ecosystem services. (Non ' 0 ' ES (ecosystem service) score includes,,,+++--- scores only; \% of times that a scale of benefit recorded for each ecosystem service, excluding all ' 0 ' values).

\begin{tabular}{|c|c|c|c|c|c|c|c|c|}
\hline Ecosystem service & Local & City & Regional & National & Global & TOTAL & $\begin{array}{l}\text { Non } \\
\text { ‘0’ ES } \\
\text { score }\end{array}$ & $\begin{array}{l}\text { \% of ES } \\
\text { recorded }\end{array}$ \\
\hline Fresh water & 18 & 12 & 0 & 0 & 1 & 31 & 34 & 91.18 \\
\hline Food & 9 & 44 & 0 & 0 & 0 & 53 & 54 & 98.15 \\
\hline Fibre and fuel & 15 & 0 & 0 & 0 & 0 & 15 & 15 & 100.00 \\
\hline Genetic resources & 5 & 12 & 0 & 5 & 0 & 22 & 26 & 84.62 \\
\hline Biochemicals, medicines, pharmaceuticals & 34 & 15 & 0 & 0 & 0 & 49 & 50 & 98.00 \\
\hline Ornamental resources & 3 & 5 & 0 & 0 & 0 & 8 & 8 & 100.00 \\
\hline Clay, mineral, aggregate harvesting & 0 & 2 & 0 & 0 & 0 & 2 & 2 & 100.00 \\
\hline Waste disposal & 24 & 13 & 0 & 0 & 0 & 37 & 37 & 100.00 \\
\hline Energy harvesting & 0 & 1 & 0 & 0 & 0 & 1 & 1 & 100.00 \\
\hline Air quality regulation & 36 & 17 & 0 & 0 & 0 & 53 & 53 & 100.00 \\
\hline Climate regulation - local & 39 & 15 & 0 & 0 & 1 & 55 & 56 & 98.21 \\
\hline Climate regulation - global & 0 & 3 & 0 & 0 & 30 & 33 & 33 & 100.00 \\
\hline Water regulation & 0 & 52 & 0 & 0 & 0 & 52 & 52 & 100.00 \\
\hline Natural hazard regulation & 9 & 16 & 0 & 0 & 0 & 25 & 26 & 96.15 \\
\hline Pest regulation & 38 & 10 & 0 & 0 & 0 & 48 & 52 & 92.31 \\
\hline Disease regulation - human & 27 & 1 & 0 & 0 & 0 & 28 & 28 & 100.00 \\
\hline Disease regulation - stock & 8 & 0 & 0 & 0 & 0 & 8 & 8 & 100.00 \\
\hline Erosion regulation & 21 & 14 & 0 & 0 & 0 & 35 & 35 & 100.00 \\
\hline Water purification and waste treatment & 9 & 25 & 0 & 0 & 0 & 34 & 39 & 87.18 \\
\hline Pollination & 37 & 16 & 0 & 0 & 0 & 53 & 55 & 96.36 \\
\hline Salinity regulation, fire regulation & 1 & 15 & 0 & 0 & 0 & 16 & 19 & 84.21 \\
\hline Noise and visual buffering & 27 & 14 & 0 & 0 & 0 & 41 & 41 & 100.00 \\
\hline Cultural heritage & 13 & 5 & 0 & 3 & 0 & 21 & 21 & 100.00 \\
\hline Recreation and tourism & 2 & 21 & 0 & 0 & 2 & 25 & 27 & 92.59 \\
\hline Aesthetic value & 23 & 19 & 0 & 0 & 0 & 42 & 43 & 97.67 \\
\hline Spiritual and religious value & 2 & 3 & 0 & 1 & 0 & 6 & 6 & 100.00 \\
\hline Inspiration of art, folklore, & 10 & 9 & 0 & 1 & 0 & 20 & 21 & 95.24 \\
\hline Social relations & 14 & 24 & 0 & 0 & 0 & 38 & 38 & 100.00 \\
\hline Educational and research & 1 & 37 & 0 & 1 & 1 & 40 & 44 & 90.91 \\
\hline Soil formation & 24 & 8 & 0 & 0 & 0 & 32 & 32 & 100.00 \\
\hline Primary production & 18 & 19 & 1 & 1 & 0 & 39 & 39 & 100.00 \\
\hline Nutrient cycling & 38 & 11 & 0 & 0 & 0 & 49 & 51 & 96.08 \\
\hline Water recycling & 26 & 12 & 0 & 0 & 0 & 38 & 38 & 100.00 \\
\hline Photosynthesis & 16 & 17 & 1 & 1 & 4 & 39 & 39 & 100.00 \\
\hline Provision of habitat & 11 & 23 & 15 & 0 & 2 & 51 & 52 & 98.08 \\
\hline
\end{tabular}

Variations in the scale at which the benefits were delivered were observed across the four major classes of ecosystem service. Overall, $93.77 \%$ of the benefits accrued through the ecosystem services occurred at the local or city scale, with $2.63 \%$ at the regional and national level and a further $3.60 \%$ at the global scale. This demonstrates a high 'Colombo-centric' distribution of the benefits of the wetlands. For provisioning services, the strength of the linkage between the wetlands and their benefits for Colombo is even stronger, with $97.25 \%$ of all benefits accruing within the city. More than half (52.39\%) of all the benefits delivered through regulating services occur at the local scale around the wetlands. Regulating services, primarily through regulation of global climate, also make 
the largest contribution at a global scale (6.44\%). Cultural services predominate at the city scale (64.46\%). Just over $10 \%$ of supporting services make a contribution beyond the local or city scale.

Therefore the distribution of benefits derived from the wetlands is strongly skewed towards the city level. However, there are subtle differences among ecosystem services and the scale at which they deliver benefits. Several ecosystem services uniquely provide benefits at the city scale (Table 4). For instance, food, air quality regulation, pest regulation, water regulation through the control of flooding and pollination are all abundantly and uniquely provided to the citizens of Colombo. Conversely, global climate regulation is unsurprisingly delivered at the global scale. The provision of habitat, and the importance it has in supporting species of conservation concern and acting as a supporting service to other ecosystem services, makes the largest contribution of all the ecosystem services at the regional/national scale beyond Colombo.

\section{Discussion}

\subsection{Is the approach 'rapid'?}

Wetland decision-makers, and especially those in poorly resourced parts of the world, need simple, user-friendly, cost-effective tools that enable them to systematically understand and protect wetlands and the important ecosystem services they provide (Carletti et al., 2004; Mclnnes et al. 2016b). Numerous techniques exist for assessing the benefits provided by wetlands. Fennessey et al. (2007) reviewed more than 40 and Bagstad et al. (2013) evaluated 17 different ecosystem services assessment tools. High time, cost or data requirements limit the utility of many of these approaches (Bagstad, et al., 2013) and many fail to meet the Fennessey et al. (2007) definition of rapid.

However, challenges exist in transferring one rapid assessment method to another geographical location (Gaucherand et al. 2015). The development of the RAWES approach has been cognisant of this, as well as the wider requirements for the development of a rapid assessment technique (Sutula et al., 2006), and has steered away from using reference condition or reference datasets through the recognition that wetland sites vary widely. Stein et al. (2009) defined the intent of wetland rapid assessment techniques as a requirement to evaluate the complex ecological conditions using a finite set of observable field indicators, and to express the relative condition of a particular site in a manner that informs ecosystem management. Through the use of trained assessors interpreting a variety of field indicators, the RAWES approach has achieved the assessment of 35 different wetland ecosystem services at the field sites in Colombo. However, particular shortcomings in the use of indicators were observed for the assessment of disease regulation in stock and the presence of social relations. The reduced level of recognition of whether a particular wetland was regulating disease in stock could be down to the more fundamental issue surrounding the complexity of whether biodiversity either increases or decreases disease transmission (Keesing et al., 2010) or it may simply be a result of the lack of observable or acquired evidence for the presence of livestock.

One of the objectives of the RAWES approach was satisfy the definition of 'rapid' as proposed by Fennessey et al. (2007) insofar that no more than two people should spend more than half a day in the field and another half day of preparation and analysis. This definition has also been adopted as the definition of rapid for assessment of wetlands in South Africa (Kotze et al. 2012). This is significantly different to the definition of 'rapid' entailed in implementation of techniques such as the Toolkit for Ecosystem Service at Site-based Assessment (TESSA), which may require tens of days with associated expenses for an individual site assessment (Peh et al. 2013). On average, the assessments of the wetlands in the CMR took less than three hours per site using the RAWES approach, including data preparation and post-assessment data entry, conforming comfortably to the Fennessey et al. (2007) definition of rapid. However, in the pursuit of rapidity and the

McInnes, R.J., Everard, M. (2017) Rapid Assessment of Wetland Ecosystem Services (RAWES): An example from Colombo, Sri 
requirement to satisfy requirements of wetland managers, especially with regards to reporting on internationally important wetlands (McInnes et al., 2016b), it is clear that trade-offs will exist between time and data constraints and scientific precision. Therefore, further analysis of the comprehensive studies completed as part of the development of a wetland management strategy for the CMR (Mclnnes et al., 2016c) would be desirable to evaluate more fully the precision or otherwise of the rapid assessments. However, the results of some of these studies, especially those that investigated wetland soils, provision of habitat, flooding regimes, recreation and tourism and participatory rural appraisals, supported the overall conclusions derived through the RAWES approach.

\subsection{Does the approach deliver objective and repeatable results?}

Appropriate training of assessors is considered important for the implementation of rapid wetland assessment techniques and has been demonstrated to deliver successful results (Carletti et al. 2004).The use of well-informed, trained, local assessors has contributed to the comprehensive scope of the assessment outputs. The training process itself is also rapid, typically a one-day explanatory session, a half-day spent making field assessments with expert assessors available on site as coaches followed by a half-day debriefing session. This approach is similar to that adopted elsewhere for the robust assessment of wetland environments (Fox et al., 1998).The RAWES approach also builds local capacity in the interpretation of wetland ecosystem services and indeed in other habitats. The approach recognises the critical role that local people can play in generating locally relevant data on ecosystem services that has been recognised in other assessment approaches, for instance in the development of TESSA (Peh et al. 2013) and applying local knowledge for determining the relative importance and relevance of different ecological thresholds in national assessments of ecosystem services (Herrick et al. 2010).

The results generated though the application of the RAWES approach are only as good as the assessors applying it. Similar field-based assessment techniques have demonstrated how the potential subjectivity of field assessors can be minimised through the use of concise definitions, field testing and appropriate training (Fox et al. 1998). The use of clear narratives on indicators and targeted training has also been demonstrated to enhance the repeatability of assessments and minimise observer error (Sutula et al., 2006). Furthermore, the experience level of the observer can have a limiting impact on the repeatability of the final rapid assessment score, whereas training, however, can have a large impact on observer-to-observer repeatability (Herlihy et al. 2009). The combination of pairs of well-informed local assessors, with an inherent comprehension of wetlands, coupled with dedicated training sessions was considered essential to the success of applying the RAWES approach. To evaluate more fully the reliability of the assessment outputs, it would be necessary to validate them against independent data (Stein et al. 2009), something beyond the scope of this project. However, as observed by Fennessey et al. (2007), the common use of categories, such as "high", "medium" or "low", or ++ or 0 as utilised in the RAWES approach, whilst decreasing sensitivity, tends to reduce the variability in scoring, resulting in less measurement error and making results repeatable and the method more robust.

It is accepted that the RAWES approach does not measure ecosystem services directly but uses proxies, through a series of questions about indicators, for their identification and evaluation. Whilst proxies might not adequately capture all critical information (Bennett et al. 2009), their use has been applied elsewhere for the assessment of wetland ecosystem services (Janssen et al. 2005; Maltby, 2009). The ability of the assessors to undertake assessments of all the ecosystem services indicates that the indicators and simple narratives provided had utility. However, limitations were identified with regards to understanding the role of disease regulation in stock and, to a lesser degree, the importance of social relations. The use of service-specific indicators can also be considered a more robust approach than one which simply considers land use/cover as often these may be based on

McInnes, R.J., Everard, M. (2017) Rapid Assessment of Wetland Ecosystem Services (RAWES): An example from Colombo, Sri 
false assumptions (Koch et al. 2009). A significant challenge in applying such an approach was highlighted by Cole (2006) insofar as the use of proxies moves us further and further from actual data, and therefore what can any one of us truly say as what our indices are telling us ecologically? However, the use of proxies and the dependence on best professional judgement is widely used to evaluate a variety of metrics in the HGM approach in the United States of America (Whigham et al. 1999; Jacobs et al. 2010) and can be considered to represent a legitimate and robust approach. Notwithstanding this, there remains the possibility that the assessors have incorrectly considered the indicators and undertaken an erroneous evaluation. Nevertheless, a data-intensive approach to assessment of a multiplicity of services is generally not practical (and certainly was not feasible in the context of the wider wetland management strategy study), is subject to data gap and quality errors and biased towards readily-measured services, and is therefore unlikely to combine rapidity with comprehensive coverage across all ecosystem services. Notwithstanding this, it is acknowledged, as has been observed in wider critiques of other wetland rapid assessment approaches (Thiesing, 2001), that the RAWES approach will have its limitations, will have a lower degree of reproducibility than data-intensive approaches and will involve a degree of subjectivity in the results.

\subsection{Does the approach consider the multiplicity of ecosystem services?}

Criticism has been levelled at several ecosystem service assessments through a failure to consider adequately the multiplicity of benefits (Balmford et al. 2011; Everard and Mclnnes, 2013). The application of the RAWES approach in the CMR considered and conducted assessments of 35 different ecosystem services. The field assessors felt confident that there were appropriate and observable field indicators, and that their collective knowledge of the wetlands was sufficient and/or that dialogue with local stakeholders yielded robust enough information for assessments to be completed on 33 services at over $95 \%$ of the sites. Only two services, the regulation of disease in stock and presence of social relations, were considered to require additional information to complete the assessment at more than $5 \%$ of the sites.

The specific requirement of the RAWES approach to consider the supporting services provides fundamental information on the functioning of the wetlands and their resilience to change. The information collected on supporting services, which have been poorly considered in other assessments of urban wetlands (McInnes, 2013a), is also considered essential if efforts are to be made restore wetland functioning and enhance future delivery of ecosystem services (Benayas et al., 2009).

The RAWES approach assesses value in purely nominal terms, with no intent to convert this into a quantifiable or monetary metric. Similarly, the approach identifies relative value and describes broad level beneficiaries but does not profess to generate standardised units for accounting purposes (Boyd and Banzhaf, 2007). Rather the approach provides an initial screening, or as advocated in TEEB (2010), it assists with recognizing ecosystem services as part of a hierarchical approach to defining value. Such qualitative assessments of wetland ecosystem system services are known to provide useful information for initial screening, scoping, or coarse-grain ranking processes (Bagstad et al., 2013; Russi et al., 2013). However, the assessments undertaken in Colombo should only be considered as a snapshot of the status of the wetlands at a point in time and greater understanding of the functioning of the systems would require repeated assessments over time (Stein et al., 2009). Similarly, the use of a five-point scale can imply equal weighting to services (for instance two different services could be assigned a score of ++ ) when a more detailed quantified assessment could illustrate considerable differences in their importance. Similarly, aggregating scores for multiple services at one site would be subjective and potentially provide meaningless results. The value of the approach is not in providing a single score or aggregated metric to represent the 
ecosystem services delivered by one site, but rather to provide an overview of the multiplicity of benefits provided by individual and multiple wetlands.

\subsection{Does the approach provide information on the scale of benefits?}

The issue of assessing the spatial scale at which the benefits of ecosystem services accrue has been highlighted as being problematic (Hein et al., 2006). However, it is essential to take issues of scale into account to achieve comprehensive assessment (de Groot et al. 2010). Application of the RAWES approach across the wetlands of the CMR made this assessment tractable, and provided comprehensive information on the spatial scale of benefit for more than half of all the services considered. However, there were several services, including provision of genetic resources, water purification, salinity regulation and education and research, where insufficient information was available to undertake an assessment of the spatial scale of benefit limiting the utility of the approach. Providing improved understanding of the spatial scale of benefits is essential to future developments of the RAWES approach, as it is for wider understanding of ecosystem services (Hein et al. 2006).

\subsection{Can the results be subjected to statistical analysis?}

As with many other rapid assessment techniques (Carletti et al., 2004; Bagstad et al., 213), the RAWES approach provides assessment 'scores' as a nominal scale that can be normalized into a dimensionless numerical index. The numerical scale generated has been used to conduct a range of statistical analyses. The objective of the analysis has been to test for possible significant correlations among the nominal data, by using Pearson's correlation, and to illustrate possible relationships using statistical tests, such as through the use of the PCA bi-plot. Given the limitations associated with nominal any further statistical testing would not be advised.

\subsection{Implications for urban wetland management in Colombo}

The wetlands of Colombo are under threat (Hettiarachchi et al., 2014a; Samarasinghe \& Dayawansa, 2013). Despite the fact that the quality of life for urban citizens is known to be improved by locally generated services (Bolund and Hunhammar, 1999) wetland loss and destruction has continued apace. Application of the RAWES approach in the CMR allowed a city-wide assessment of a multiplicity of ecosystem services to be undertaken. However, even when considered as a snapshot in time, the assessment of the 62 different wetland sites across Colombo highlighted numerous ecosystem services that had not been formally recognised in previous assessments of wetlands investigated within or around the city (Emerton and Kekulandala, 2003; Wattage and Mardle, 2008; Hettiarachchi et al., 2014a). The results of the RAWES approach highlighted significant environmentlivelihoods aspects which have been considered important for similar wetland systems in Sri Lanka (Sellamuttu et al., 2011) and also provided information in order to address the concern that some wetlands in Colombo are no longer considered a valuable resource by the community (Hettiarachchi et al., 2014a). The identification of 35 different and diverse ecosystem services has the ability to broaden the discussion around the importance of wetlands within Colombo and presents values based on ecosystem services rather than values based solely on nature conservation (Hettiarachchi et al., 2014c). Consequently, irrespective of the inherent subjectivity around the use of a rapid technique, the ability to recognise a multiplicity of wetland ecosystem services has made a significant contribution to discussions around the future wise use of wetlands in urban Colombo (Mclnnes et al., 2016c).

Through the use of simple graphics (such as Figure 2), the application of the RAWES approach assisted significantly in demonstrating the importance of wetlands to decision-makers in Sri Lanka. Differences among the wetland types were articulated in the strategy and the potential future trajectories of change were inferred from the agglomeration of sites by services. The outputs of the RAWES assessment confirm the conclusions drawn in the wider published literature on the wetlands

McInnes, R.J., Everard, M. (2017) Rapid Assessment of Wetland Ecosystem Services (RAWES): An example from Colombo, Sri 
of Colombo (Wattage and Mardle 2005; Sellamuttu et al., 2011; Hettiarachchi et al., 2014a, Hettiarachchi et al., 2014b) and also highlight additional benefits which were previously unreported, such as the importance of the wetlands for regulating air quality, storing carbon and controlling pest species. The information provided by the application of the RAWES approach highlighted the need to conserve and restore these critical habitats as a principal priority for the city and has contributed significantly within the urban planning context (Mclnnes et al. 2016c).

\subsection{Future developments}

Whilst the RAWES approach has been trialled at several sites in different wetlands, the application in the CMR is the first comprehensive application of the approach. Experience so far suggests that, by working in collaboration with well-informed and trained local assessors, the RAWES approach can yield robust and repeatable results on a multitude of ecosystem services. There are some limitations in the approach (such as with assessing specific services including regulation of pests in stock and the scale of benefit from genetic resources). Nevertheless, further field testing and the development of improved indicators is on-going. Issues of the spatial scale at which the benefits accrue are adequately addressed but improvements are still required to progress this further. Additionally, validation of assessment outcomes against empirical data would enhance confidence in the veracity of RAWES outputs.

The genuinely 'rapid' nature of the RAWES approach potentially broadens its utility, and the comprehensive coverage of all linked ecosystem services is an important aspect of assessment outputs. Repeat assessments over time could be conducted in order to evaluate conservation outcomes or changes in protection/designation status of wetlands. For instance, the success of the wetland management strategy proposed for the CMR (Mclnnes et al. 2016b) could use the assessments conducted in this study as representing the baseline conditions at a point in time and future success, or otherwise, could be measured against these outcomes. Additionally, the Ramsar Convention adopted Resolution XI.8 (2012), which proposed a revision to the recording of information on ecosystem services on the Information Sheet on Ramsar Wetlands (RIS). Consequently there is a need to ensure that an assessment is made of a broad range of ecosystem services for Ramsar Sites in accordance with the reporting obligations. The RAWES approach has potential utility in facilitating such reporting within the time and resource restrictions of Ramsar Site Managers.

\section{Acknowledgements}

The field assessments were conducted as part of the World Bank funded Metro Colombo Urban Development Project (MCUDP/PHRD/03) under "The consultancy services for the preparation of a management strategy for wetlands and carrying out an assessment of water quality in the inland waterways and lakes within Metro Colombo area". The authors would like to thank the lead consultants - Signes along with all the other consultants that worked on the wider project, as well as staff from the Sri Lanka Land Reclamation and Development Corporation (SLLRDC) and the World Bank. Special thanks are given to the local assessors from the Green Movement for their efforts on the ground, and to our colleagues Lalith Amaral and Anusha Bandara who provided particular insights into the ecosystem services provided by the wetlands of Colombo.

\section{References}

Bagstad, K. J., Semmens, D. J., Waage, S., \& Winthrop, R. (2013). A comparative assessment of decisionsupport tools for ecosystem services quantification and valuation. Ecosystem Services, 5, 27-39. 
Balmford, A., Fisher, B., Green, R. E., Naidoo, R., Strassburg, B., Turner, R. K., \& Rodrigues, A. S. (2011). Bringing ecosystem services into the real world: an operational framework for assessing the economic consequences of losing wild nature. Environmental and Resource Economics, 48(2), 161-175.

Benayas, J. M. R., Newton, A. C., Diaz, A., \& Bullock, J. M. (2009). Enhancement of biodiversity and ecosystem services by ecological restoration: a meta-analysis. Science, 325(5944), 1121-1124.

Braat, L.C. \& de Groot, R. (2012). The ecosystem services agenda: bridging the worlds of natural science and economics, conservation and development, and public and private policy. Ecosystem Services, 1, pp.4-15.

Bennett, E. M., Peterson, G. D., \& Gordon, L. J. (2009). Understanding relationships among multiple ecosystem services. Ecology letters, 12(12), 1394-1404.

Bolund, P., \& Hunhammar, S. (1999). Ecosystem services in urban areas. Ecological economics, 29(2), $293-301$.

Boyd, J., \& Banzhaf, S. (2007). What are ecosystem services? The need for standardized environmental accounting units. Ecological economics, 63(2), 616-626.

Cachelin, A., Paisley, K., \& Blanchard, A. (2009). Using the significant life experience framework to inform program evaluation: The nature conservancy's wings \& water wetlands education program. The Journal of Environmental Education, 40(2), 2-14.

Carletti, A., Leo, G. A. D., \& Ferrari, I. (2004). A critical review of representative wetland rapid assessment methods in North America. Aquatic Conservation: Marine and Freshwater Ecosystems, 14(S1), S103-S113.

Cole, C. A. (2006). HGM and wetland functional assessment: six degrees of separation from the data?. Ecological indicators, 6(3), 485-493.

Costanza, R., d'Arge, R., de Groot, R.S., Farber, S., Grasso, M., Hannon, B., Limburg, K., Naeem, S., O'Neill, R.V., Paruelo, J., Raskin, R.G., Sutton, P., van den Belt, M. (1997) The value of the world's ecosystem services and natural capital. Nature 387, 253-60.

Daily, G. C., \& Matson, P. A. (2008). Ecosystem services: from theory to implementation. Proceedings of the National Academy of Sciences, 105(28), 9455-9456.

Davidson, N. C. (2014). How much wetland has the world lost? Long-term and recent trends in global wetland area. Marine and Freshwater Research, 65(10), 934-941.

Defra. (2007), An introductory guide to valuing ecosystem services. Department for Environment Food and Rural Affairs (Defra) [online]. pp. 68. Available from: www.defra.gov.uk.

De Groot, R. S., Alkemade, R., Braat, L., Hein, L., \& Willemen, L. (2010). Challenges in integrating the concept of ecosystem services and values in landscape planning, management and decision making. Ecological complexity, 7(3), 260-272.

Dhote, S., \& Dixit, S. (2009). Water quality improvement through macrophytes-a review. Environmental Monitoring and Assessment, 152(1-4), 149-153.

Ebert, U., \& Welsch, H. (2004). Meaningful environmental indices: a social choice approach. Journal of Environmental Economics and Management, 47(2), 270-283.

Emerton, L. D. \& Kekulandala, C.B. (2003). Assessment of the Economic Value of Muthurajawela Wetland. Occ. Pap. IUCN.Sri Lanka., 4:iv + 28pp.

Emmanuel, R. (2005). Thermal comfort implications of urbanization in a warm-humid city: the Colombo Metropolitan Region (CMR), Sri Lanka. Building and Environment, 40(12), 1591-1601.

Emmanuel, R., \& Johansson, E. (2006). Influence of urban morphology and sea breeze on hot humid microclimate: the case of Colombo, Sri Lanka. Climate research, 30(3), 189-200.

Everard, M. (2016) The Ecosystems Revolution. Palgrave MacMillan. 177pp.

Everard, M. \& McInnes, R.J. (2013). Systemic solutions for multi-benefit water and environmental management. Science of the Total Environment, 461, 170-179.

Everard, M., McInnes, R.J. and Gouda, H. (2016). Progress with integration of ecosystem services in sustainable drainage systems. In: Booth, C.A. and Charlesworth, S.M. (Eds.) Sustainable Surface Water Management. Wiley-Blackwell, Chichester.

Everard M. \& Waters R. (2013) Ecosystem services assessment: How to do one in practice (Version 1, October 13 2013). Institution of Environmental Sciences, London. www.ies-uk.org.uk/resources/ecosystem-servicesassessment accessed 16 September 2016

Faulkner, S. (2004). Urbanization impacts on the structure and function of forested wetlands. Urb. Ecosys. 7, 89-106.

Fennessy, M. S., Jacobs, A. D., \& Kentula, M. E. (2007). An evaluation of rapid methods for assessing the ecological condition of wetlands. Wetlands, 27(3), 543-560.

Finlayson, C.M., Bartlett, M., Davidson, N \& McInnes, R.J. (2013) The Ramsar Convention and urban wetlands: an opportunity for wetland education and training. In Paul, S. (Ed). (2013). 'Workbook for managing urban

McInnes, R.J., Everard, M. (2017) Rapid Assessment of Wetland Ecosystem Services (RAWES): An example from Colombo, Sri Lanka. Ecosystem Services. DOI: 10.1016/j.ecoser.2017.03.024 
wetlands in Australia'. 1st edn. (Sydney Olympic Park Authority), eBook available through www.sopa.nsw.gov.au/education/WETeBook/, ISBN 978-0-9874020-0-4.

Fox, P. J., Naura, M., \& Scarlett, P. (1998). An account of the derivation and testing of a standard field method, River Habitat Survey. Aquatic Conservation: Marine and Freshwater Ecosystems, 8(4), 455-475.

Fraser, D. J., Coon, T., Prince, M. R., Dion, R., \& Bernatchez, L. (2006). Integrating traditional and evolutionary knowledge in biodiversity conservation: a population level case study. Ecology and Society, 11(2), 4.

Gagnon, C. A., \& Berteaux, D. (2009). Integrating traditional ecological knowledge and ecological science: a question of scale. Ecology and Society, 14(2), 19.

Gardner, R.C. and Davidson, N.C. (2011) The Ramsar Convention. In B. Le Page (editor). Wetlands: Integrating Multidisciplinary Concepts. Dordrecht: Springer. pp.189-203.

Gaucherand, S., Schwoertzig, E., Clement, J. C., Johnson, B., \& Quétier, F. (2015). The Cultural Dimensions of Freshwater Wetland Assessments: Lessons Learned from the Application of US Rapid Assessment Methods in France. Environmental management, 56(1), 245-259.

Gedan, K. B., Kirwan, M. L., Wolanski, E., Barbier, E. B., \& Silliman, B. R. (2011). The present and future role of coastal wetland vegetation in protecting shorelines: answering recent challenges to the paradigm. Climatic Change, 106(1), 7-29.

Ghermandi, A., Van Den Bergh, J. C., Brander, L. M., De Groot, H. L., \& Nunes, P. A. (2010). Values of natural and human-made wetlands: A meta-analysis. Water Resources Research, 46(12).

Harrington, R. \& McInnes, R. (2009). Integrated Constructed Wetlands (ICW) for livestock wastewater management. Bioresource Technology, 100(22), 5498-5505.

Hein, L., Van Koppen, K., De Groot, R. S., \& Van lerland, E. C. (2006). Spatial scales, stakeholders and the valuation of ecosystem services. Ecological economics, 57(2), 209-228.

Herlihy, A. T., Sifneos, J., Bason, C., Jacobs, A., Kentula, M. E., \& Fennessy, M. S. (2009). An approach for evaluating the repeatability of rapid wetland assessment methods: the effects of training and experience. Environmental management, 44(2), 369-377.

Herrick, J. E., Lessard, V. C., Spaeth, K. E., Shaver, P. L., Dayton, R. S., Pyke, D. A., Jolley, L. \& Goebel, J. J. (2010). National ecosystem assessments supported by scientific and local knowledge. Frontiers in Ecology and the Environment, 8(8), 403-408.

Hettiarachchi, M. 2008. Integrating multidisciplinary information for urban flood control through proper management of wetlands: A Case Study of Kolonnawa Marshlands (Sri Lanka). In: Urban Waters: Resource or Risk? In Proceedings of the $7^{\text {th }}$ World Wide Workshop for Young Environmental Scientists (WWW YES 2008), 13-16 May 2008,.Université Paris-Est CEREVE, France.

Hettiarachchi, M., Morrison, T. H., Wickramsinghe, D., Mapa, R., De Alwis, A., \& McAlpine, C. A. (2014a). The eco-social transformation of urban wetlands: A case study of Colombo, Sri Lanka. Landscape and Urban Planning, 132, 55-68.

Hettiarachchi, M., Athukorale, K., Wijekoon, S., \& de Alwis, A. (2014b). Urban wetlands and disaster resilience of Colombo, Sri Lanka. International Journal of Disaster Resilience in the Built Environment, 5(1), 79-89.

Hettiarachchi, M., McAlpine, C., \& Morrison, T. H. (2014c). Governing the urban wetlands: a multiple casestudy of policy, institutions and reference points. Environmental Conservation, 41(03), 276-289.

Jacobs, A. D., Kentula, M. E., \& Herlihy, A. T. (2010). Developing an index of wetland condition from ecological data: an example using HGM functional variables from the Nanticoke watershed, USA. Ecological Indicators, 10(3), 703-712.

Janssen, R., Goosen, H., Verhoeven, M. L., Verhoeven, J. T., Omtzigt, A. Q. A., \& Maltby, E. (2005). Decision support for integrated wetland management. Environmental Modelling \& Software, 20(2), 215-229.

Jayaweera, M. W., Kasturiarachchi, J. C., Kularatne, R. K., \& Wijeyekoon, S. L. (2008). Contribution of water hyacinth (Eichhornia crassipes (Mart.) Solms) grown under different nutrient conditions to Fe-removal mechanisms in constructed wetlands. Journal of environmental management, 87(3), 450-460.

Keesing, F., Belden, L. K., Daszak, P., Dobson, A., Harvell, C. D., Holt, R. D., Hudson, P., Jolles, A., Jones, K.E., Mitchell, C.E., Myers, S.S., Bogich, T. \& Myers, S. S. (2010). Impacts of biodiversity on the emergence and transmission of infectious diseases. Nature, 468(7324), 647-652.

Koch, E.W., Barbier, E.B., Silliman, B.R., Reed, D.J., Perillo, G.M.E., Hacker, S.D., Granek, E.F., Primavera, J.H., Muthiga, N., Polasky, S., Halpern, B.S., Kennedy, C.J., Kappel, C.V., Wolanski, E. (2009). Non-linearity in ecosystem services: temporal and spatial variability in coastal protection. Frontiers. Ecol. Env. 7(1), 29-37.

Kotze, D. C., Ellery, W. N., Macfarlane, D. M., \& Jewitt, G. P. W. (2012). A rapid assessment method for coupling anthropogenic stressors and wetland ecological condition. Ecological Indicators, 13(1), 284-293.

McInnes, R.J., Everard, M. (2017) Rapid Assessment of Wetland Ecosystem Services (RAWES): An example from Colombo, Sri Lanka. Ecosystem Services. DOI: 10.1016/j.ecoser.2017.03.024 
Kularatne, R. K., Kasturiarachchi, J. C., Manatunge, J., \& Wijeyekoon, S. L. (2009). Mechanisms of manganese removal from wastewaters in constructed wetlands comprising water hyacinth (Eichhornia crassipes (Mart.) Solms) grown under different nutrient conditions. Water Environment Research, 81(2), 165-172.

Lannas, K. S., \& Turpie, J. K. (2009). Valuing the provisioning services of wetlands: contrasting a rural wetland in Lesotho with a peri-urban wetland in South Africa. Ecology and Society, 14(2), 18.

Maes, J., Egoh, B., Willemen, L., Liquete, C., Vihervaara, P., Schägner, J.P., Grizetti, B., Drakou, E.G., La Notte, A., Zulian, G., Bouraoui, F., Parracchini, M.L., Braat, L. \& Bidoglio G. (2012) Mapping ecosystem services for policy support and decision making in the European Union. Ecosystem Services, 1(1), 31-39

Mahanama, M. (2000). Planning and management aspects in Muthurajawela and Negombo Lagoon. in Farmer, N., ed. Workshop on Effective Management for Biodiversity Conservation in Sri Lankan Wetlands: Muthurajawela Marsh, Negombo Lagoon and Chilaw Lagoon. Report 55, Centre for the Economics and Management of Aquatic Resources, University of Portsmouth.

Maltby, E. (Ed.). (2009). Functional assessment of wetlands: towards evaluation of ecosystem services. Woodhead Publishing Limited, Cambridge, UK. 672pp

Maltby E. \& Ormerod, S. (2011) Freshwaters-Openwaters, wetlands and floodplains. In: UK National Ecosystem Assessment Technical Report. UNEP-WCMC, Cambridge, pp 295-360

Marawila, T. D. \& Thibbotuwawa, M. (2010). To Develop Or to Conserve?: The Case of the Diyawanna Oya Wetlands in Sri Lanka. South Asian Network for Development and Environmental Economics. 48pp.

McGregor, S., Lawson, V., Christophersen, P., Kennett, R., Boyden, J., Bayliss, P., Liedloff, A., McKaige, B \& Andersen, A. N. (2010). Indigenous wetland burning: conserving natural and cultural resources in Australia's World Heritage-listed Kakadu National Park. Human Ecology, 38(6), 721-729.

McInnes, R.J. (2013a). Recognising wetland ecosystem services within urban case studies. Mar. Fresh. Res. 64. 1-14.

Mclnnes, R. J. (2013b). Recognizing ecosystem services from wetlands of international importance: an example from Sussex, UK. Wetlands, 33(6), 1001-1017.

McInnes, R. J. (2014). The Ramsar Convention and SWS-delivering wetland conservation at a global level. Wetland Science \& Practice, 31(4), 12-16.

McInnes, R.J., Noupa, P., Bunu, Z.M. \& Bdliya, H.H. (2013). Sustainable Transboundary Management of Lake Chad and its Watershed: Volume 2: Evidence Base. Unpublished report for UNESCO, Contract No. 4500196802. UNESCO: Paris, France. 120pp.

McInnes, R.J., Smith, G., Greaves, J., Watson, D., Wood, N. \& Everard, M. (2016a) Multicriteria decision analysis for the evaluation of water quality improvement and ecosystem service provision. Water and Environment Journal. doi:10.1111/wej.12195

McInnes, R.J., Jaksic, S., Everard, M. Bandara, A., Amaralal, L., Weerakoon, D., Moynot, G., Salmon, G., Bargier, N., Piyadasa, R., Rigaudiere, P. and Ranwala, A. (2016c) Metro Colombo wetland management strategy . Unpublished report to Sri Lanka Land Reclamation Development Corporation and World Bank. Signes: Paris, France. 107 pp.

McInnes, R. J., Simpson, M., Lopez, B., Hawkins, R., \& Shore, R. (2016b). Wetland Ecosystem Services and the Ramsar Convention: an Assessment of Needs. Wetlands, 1-12.

Milcu, A. I., Hanspach, J., Abson, D., \& Fischer, J. (2013). Cultural ecosystem services: a literature review and prospects for future research. Ecology and Society, 18(3), 44.

Millennium Ecosystem Assessment (MA) (2005). Ecosystems and human well-being: wetlands and water synthesis. Washington (D.C.): World Resources Institute. 78pp.

Mitsch, W. J., \& Day, J. W. (2006). Restoration of wetlands in the Mississippi-Ohio-Missouri (MOM) River Basin: experience and needed research. Ecological Engineering, 26(1), 55-69.

Mohri, H., Lahoti, S., Saito, O., Mahalingam, A., Gunatilleke, N., Hitinayake, G., ... \& Herath, S. (2013). Assessment of ecosystem services in homegarden systems in Indonesia, Sri Lanka, and Vietnam. Ecosystem Services, 5, 124-136.

OGP/IPIECA (2011) Ecosystem services guidance: biodiversity and ecosystem services guide and checklists. OGP Report Number 461, OGP London, UK. 36pp

Peh, K. S. H., Balmford, A., Bradbury, R. B., Brown, C., Butchart, S. H., Hughes, F. M., Stattersfield, A., Thomas, D.H.L, Walpole, M., Bayliss, J., Gowing, D., Jones, J.P.G., Lewis, S.L., Mulligan, M., Pandeya, B., Stratford, C., Thompson, J.R., Turner, K., Vira, B., Willcock, S. and Birch, J.C. (2013). TESSA: a toolkit for rapid assessment of ecosystem services at sites of biodiversity conservation importance. Ecosystem Services, 5, 51-57.

Plieninger, T., Dijks, S., Oteros-Rozas, E., \& Bieling, C. (2013). Assessing, mapping, and quantifying cultural ecosystem services at community level. Land use policy, 33, 118-129.

McInnes, R.J., Everard, M. (2017) Rapid Assessment of Wetland Ecosystem Services (RAWES): An example from Colombo, Sri 
Resolution XI.8 (2012) Streamlining procedures for describing Ramsar Sites at the time of designation and subsequent updates. Resolutions of the 11th Meeting of the Conference of the Contracting Parties. Bucharest, Romania, 6-13 July 2012

Russi, D., ten Brink, P., Farmer, A., Badura, T., Coates, D., Forster, J., Kumar, R., Davidson, N. (2013). The Economics of Ecosystems and Biodiversity for Water and Wetlands. IEEP, London and Brussels: Ramsar Secretariat, Gland. 84pp.

Samarasinghe, Y. M. P., \& Dayawansa, N. D. K. (2013). A remote sensing and GIS based study in assessment of the degradation risk of the Kolonnawa marsh. Journal of the National Science Foundation of Sri Lanka, 41(4), 327-335.

Sellamuttu, S. S., Finlayson, C. M., Nagabhatla, N., \& Diphoorn, L. (2011). Linkages between changes in land cover (use) patterns, local perceptions and livelihoods in a coastal wetland system in Sri Lanka. Journal of the National Science Foundation of Sri Lanka, 39(4), 391-402.

Seppelt, R., Dormann, C.F., Eppink, F.V., Lautenbach, S., \& Schmidt, S. (2011) A quantitative review of ecosystem service studies: approaches, shortcomings and the road ahead. Journal of Applied Ecology 48(3):630-636

Shutes, R. B. E. (2001). Artificial wetlands and water quality improvement. Environment international, 26(5), 441-447.

Spangenberg, J. H., \& Settele, J. (2010). Precisely incorrect? Monetising the value of ecosystem services. Ecological Complexity, 7(3), 327-337.

Stein, E. D., Brinson, M., Rains, M. C., Kleindl, W., \& Hauer, F. R. (2009). Wetland assessment debate: wetland assessment alphabet soup: how to choose (or not choose) the right assessment method. The Society of Wetland Scientists Bulletin, 26(4), 20-24.

Stratford, C. J., Acreman, M. C., \& Rees, H. G. (2011). A simple method for assessing the vulnerability of wetland ecosystem services. Hydrological Sciences Journal, 56(8), 1485-1500.

Sun, R., Chen, A., Chen, L., \& Lü, Y. (2012). Cooling effects of wetlands in an urban region: the case of Beijing. Ecological Indicators, 20, 57-64.

Sutula, M. A., Stein, E. D., Collins, J. N., Fetscher, A. E., \& Clark, R. (2006). A practical guide for the development of a wetland assessment method: the California experience. JAWRA Journal of the American Water Resources Association, 42(1), 157-175.

TEEB (2010). The economics of ecosystems and biodiversity: mainstreaming the economics of nature: a synthesis. Available at: http://www.teebweb.org [accessed 26 September 2016].

Thiesing, M.A. (2001). An evaluation of wetland assessment techniques and their applications to decision making. In Finlayson, C.M., Davidson, N.C. \& Stevenson, N.J. (eds) 2001. Wetland inventory, assessment and monitoring: Practical techniques and identification of major issues. Proceedings of Workshop 4, 2nd International Conference on Wetlands and Development, Dakar, Senegal, 8.14 November 1998, Supervising Scientist Report 161, Supervising Scientist, Darwin. 87-96.

Turner, R.K., Georgiou, S. \& Fisher, B. (2008) Valuing ecosystem services: the case of multi functional wetlands. London: Earthscan

UNEP-WCMC (2013) Incorporating biodiversity and ecosystem service values into NBSAPS: Guidance to support NBSAP practitioners. UNEP-WCMC, Cambridge, UK. 92pp.

van den Bergh, J. C., \& van Veen-Groot, D. B. (2001). Constructing aggregate environmental-economic indicators: a comparison of 12 OECD countries. Environmental economics and policy studies, 4(1), 1-16.

Verhoeven, J. T., \& Setter, T. L. (2009). Agricultural use of wetlands: opportunities and limitations. Annals of botany, mcp172.

Vihervaara, P., Rönkä, M., \& Walls, M. (2010). Trends in ecosystem service research: early steps and current drivers. Ambio, 39(4), 314-324.

Villa, F., Bagstad, K. J., Voigt, B., Johnson, G. W., Portela, R., Honzák, M., \& Batker, D. (2014). A methodology for adaptable and robust ecosystem services assessment. PloS one, 9(3), e91001.

Vira, B., \& Adams, W. M. (2009). Ecosystem services and conservation strategy: beware the silver bullet. Conservation Letters, 2(4), 158-162.

Waage, S. \& Stewart, E. (2008). Ecosystem Services Management: A Briefing on Relevant Public Policy Developments and Emerging Tools. Fauna \& Flora International.

Wattage, P., \& Mardle, S. (2005). Stakeholder preferences towards conservation versus development for a wetland in Sri Lanka. Journal of Environmental Management, 77(2), 122-132.

WBCSD (2011) Guide to corporate ecosystem valuation: a framework for improving decision-making. World Business Council for Sustainable Development (WBCSD), Geneva, Switzerland 78pp 
Whigham, D. F., Lee, L. C., Brinson, M. M., Rheinhardt, R. D., Rains, M. C., Mason, J. A., Kahn, H., Ruhlman, M.B. \& Nutter, W. L. (1999). Hydrogeomorphic (HGM) assessment-a test of user consistency. Wetlands, 19(3), 560-569.

Wijerayaratne, M. (2000). 'Coastal wetland uses and related problems in Muthurajawela Marsh and Negombo and Chilaw Lagoons'. in Farmer, N., ed. Workshop on Effective Management for Biodiversity Conservation in Sri Lankan Wetlands: Muthurajawela Marsh, Negombo Lagoon and Chilaw Lagoon. Report 55, Centre for the Economics and Management of Aquatic Resources, University of Portsmouth.

Zon, J. (2004). Wetland conservation and management in Sri Lanka. A status paper. In: IUCN Sri Lanka. Wetland conservation in Sri Lanka. Proceedings of the national symposium on wetland conservation and management. IUCN Sri Lanka: Colombo, Sri Lanka. 2-18. 